\title{
The Unconventional Cytoplasmic Sensing Mechanism for Ethanol Chemotaxis in Bacillus subtilis
}

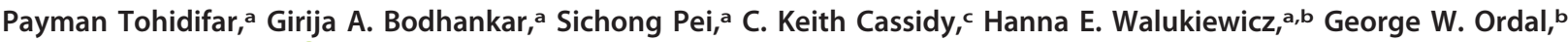 \\ Phillip J. Stansfeld, d,e (iD Christopher V. Rao
}

aDepartment of Chemical and Biomolecular Engineering, University of Illinois at Urbana-Champaign, Urbana, Illinois, USA

bDepartment of Biochemistry, University of Illinois at Urbana-Champaign, Urbana, Illinois, USA

'Department of Biochemistry, University of Oxford, Oxford, United Kingdom

aschool of Life Sciences, University of Warwick, Coventry, United Kingdom

eDepartment of Chemistry, University of Warwick, Coventry, United Kingdom

Payman Tohidifar, Girija A. Bodhankar, and Sichong Pei contributed equally to this work. Author order was determined on the basis of seniority.

ABSTRACT Motile bacteria sense chemical gradients using chemoreceptors, which consist of distinct sensing and signaling domains. The general model is that the sensing domain binds the chemical and the signaling domain induces the tactic response. Here, we investigated the unconventional sensing mechanism for ethanol taxis in Bacillus subtilis. Ethanol and other short-chain alcohols are attractants for $B$. subtilis. Two chemoreceptors, McpB and HemAT, sense these alcohols. In the case of $M c p B$, the signaling domain directly binds ethanol. We were further able to identify a single amino acid residue, $\mathrm{Ala}^{431}$, on the cytoplasmic signaling domain of $\mathrm{McpB}$ that, when mutated to serine, reduces taxis to alcohols. Molecular dynamics simulations suggest that the conversion of $\mathrm{Ala}^{431}$ to serine increases coiled-coil packing within the signaling domain, thereby reducing the ability of ethanol to bind between the helices of the signaling domain. In the case of HemAT, the myoglobin-like sensing domain binds ethanol, likely between the helices encapsulating the heme group. Aside from being sensed by an unconventional mechanism, ethanol also differs from many other chemoattractants because it is not metabolized by $B$. subtilis and is toxic. We propose that $B$. subtilis uses ethanol and other short-chain alcohols to locate prey, namely, alcohol-producing microorganisms.

IMPORTANCE Ethanol is a chemoattractant for Bacillus subtilis even though it is not metabolized and inhibits growth. B. subtilis likely uses ethanol to find ethanol-fermenting microorganisms to utilize as prey. Two chemoreceptors sense ethanol: HemAT and McpB. HemAT's myoglobin-like sensing domain directly binds ethanol, but the heme group is not involved. McpB is a transmembrane receptor consisting of an extracellular sensing domain and a cytoplasmic signaling domain. While most attractants bind the extracellular sensing domain, we found that ethanol directly binds between intermonomer helices of the cytoplasmic signaling domain of McpB, using a mechanism akin to those identified in many mammalian ethanol-binding proteins. Our results indicate that the sensory repertoire of chemoreceptors extends beyond the sensing domain and can directly involve the signaling domain.

KEYWORDS chemotaxis, Bacillus subtilis, ethanol sensing, cytoplasmic sensing, chemoreceptor, molecular dynamics, NMR, signal transduction

any bacteria move in response to external chemical gradients through a process known as chemotaxis (1). Typically, bacteria migrate up gradients of chemicals that support their growth and down ones that inhibit it. These chemicals are commonly
Citation Tohidifar P, Bodhankar GA, Pei S, Cassidy CK, Walukiewicz HE, Ordal GW, Stansfeld PJ, Rao CV. 2020. The unconventional cytoplasmic sensing mechanism for ethanol chemotaxis in Bacillus subtilis. mBio 11:e02177-20. https://doi.org/10.1128/mBio.02177-20 Editor Igor B. Zhulin, The Ohio State University Copyright $\odot 2020$ Tohidifar et al. This is an open-access article distributed under the terms of the Creative Commons Attribution 4.0 International license.

Address correspondence to Christopher V. Rao, cvrao@illinois.edu.

Received 2 August 2020 Accepted 8 September 2020

Published 6 October 2020 
sensed using transmembrane chemoreceptors, which consist of an extracellular sensing domain and a cytoplasmic signaling domain along with a cytoplasmic HAMP domain that couples the other two domains. While a number of sensing mechanisms exist, the best-understood one involves the direct binding of the chemical to the extracellular sensing domain (2). In flagellated bacteria such as Bacillus subtilis and Escherichia coli, this binding event induces a conformational change in the cytoplasmic signaling domain that alters the autophosphorylation rate of an associated histidine kinase known as CheA (3). The phosphoryl group is then transferred to a soluble response regulator known as CheY, which modulates the swimming behavior of the bacterium by changing the direction of flagellar rotation. The chemical gradients themselves are sensed using a temporal mechanism involving sensory adaptation (4).

While many chemicals are sensed by the extracellular sensing domain, some are sensed by the cytoplasmic domains, typically using an indirect mechanism. For example, sugars transported by the phosphoenolpyruvate transfer system (PTS) are indirectly sensed through interactions between the PTS proteins and chemoreceptor signaling complexes $(5,6)$. In the case of $E$. coli, changes in intracellular $\mathrm{pH}$ are sensed by the cytoplasmic HAMP domain (7). The signaling domain of $E$. coli Tar is responsible for the attractant response to toluene and $o$-xylene (8). In addition, changes in osmolarity are sensed through alterations in the packing of the chemoreceptor cytoplasmic signaling domains (9). To our knowledge, however, there have been no reports of direct sensing by the chemoreceptor cytoplasmic signaling domain. This has not been particularly surprising given that the cytoplasmic signaling domain, which consists of a long dimeric four-helix coiled coil (10), lacks an obvious ligand-binding pocket.

In this work, we investigated chemotaxis to ethanol in B. subtilis. This short-chain alcohol is an attractant for $B$. subtilis even though it is not used as a carbon source and inhibits cell growth. Ethanol is directly sensed by two chemoreceptors, HemAT and $M c p B$, inside the cytoplasm, where intracellular ethanol concentrations are similar to the extracellular concentrations due to the high permeability of the plasma membrane for short-chain aliphatic alcohols (11-16). Sensing by HemAT fits the conventional model where ethanol binds the cytoplasmic sensing domain. However, in the case of $\mathrm{McpB}$, we found that ethanol is directly sensed by the cytoplasmic signaling domain using a mechanism analogous to those of many eukaryotic ethanol-binding proteins.

\section{RESULTS}

B. subtilis exhibits chemotaxis to short-chain alcohols. We employed the capillary assay to measure $B$. subtilis chemotaxis to alcohols with increasing chain lengths $\left(C_{1}\right.$ to $C_{5}$ ). The resulting data show that $B$. subtilis exhibits chemotaxis to methanol, ethanol, 2-propanol, and tert-butanol. No significant responses to 1-propanol, 1-butanol, and 1-pentanol were observed (Fig. 1A). To elucidate the underlying sensing mechanism, we focused on ethanol because it is produced and utilized by a wide range of microorganisms in nature (17). We first measured the response to increasing ethanol concentrations using the capillary assay (Fig. 1B). Unlike many other attractants such as amino acids (18-20), a tactic response to ethanol was observed only at relatively high concentrations $(>50 \mathrm{mM})$. The ethanol response peaked at $1.78 \mathrm{M}(\sim 10 \%[\mathrm{vol} / \mathrm{vol}])$. The response decreased at higher concentrations, most likely due to ethanol being toxic at these concentrations (21). It is important to note that the reported alcohol concentrations here are the initial alcohol levels inside the capillaries, and the concentrations sensed by the cells are much lower (see Discussion).

All three adaptation systems contribute to ethanol taxis. B. subtilis employs three adaptation systems, the methylation, CheC/CheD/CheYp, and CheV systems, for sensing chemical gradients $(4,22)$. To test whether these adaptation systems are involved in ethanol taxis, we employed mutants in which these systems were selectively inactivated. We first tested ethanol taxis using a mutant ( $\Delta c h e C \Delta c h e V$ ) in which the CheC/CheD/CheYp and CheV adaptation systems were inactivated, leaving only the methylation system functional. Taxis to both ethanol and asparagine, which was used as a control, was reduced $30 \%$ in this mutant (Fig. 1C). We also observed reduced taxis 

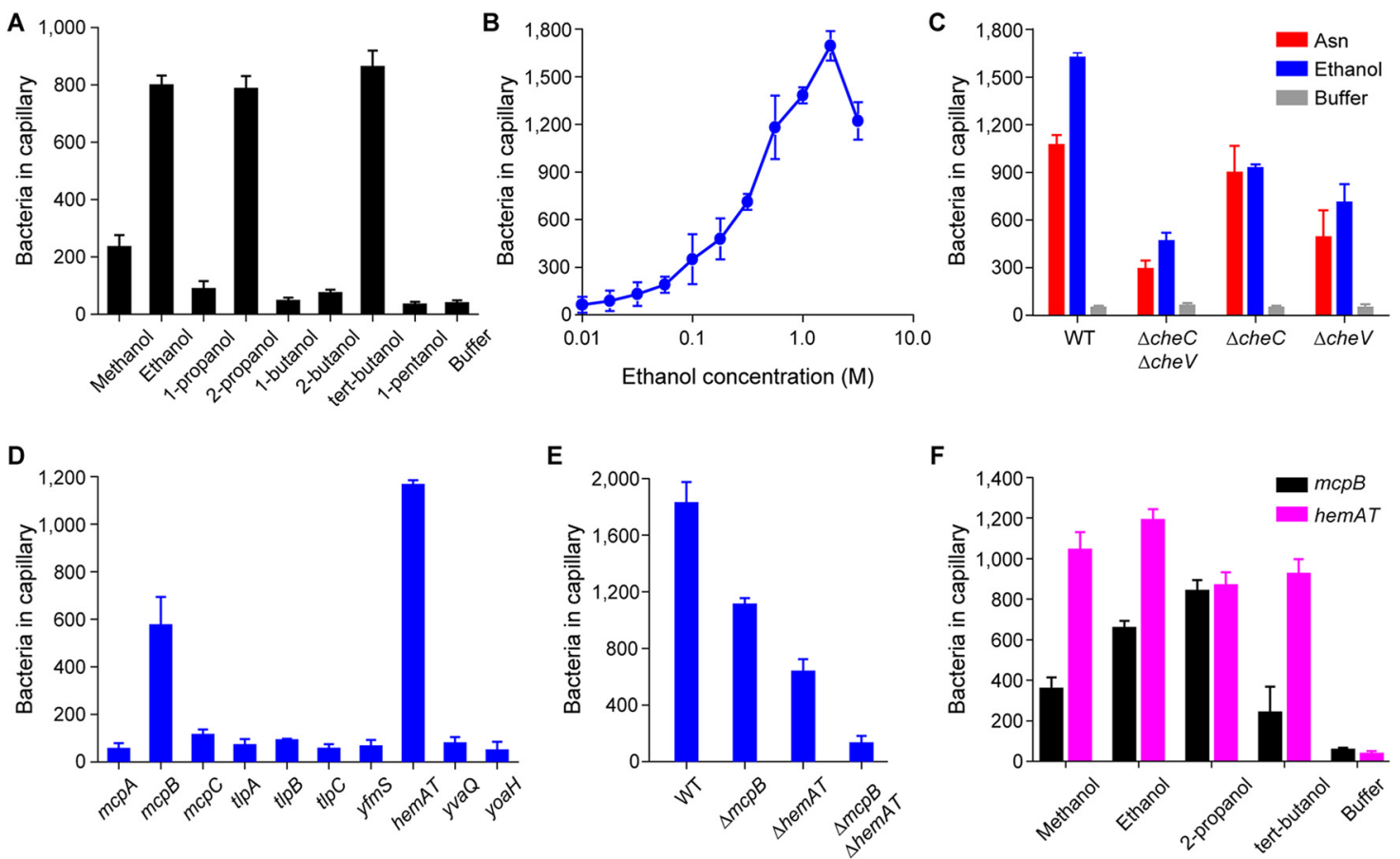

FIG 1 B. subtilis exhibits chemotaxis toward short-chain alcohols. (A) Responses of the wild-type strain to 0.5 M short-chain alcohols (in the capillaries) with increasing chain lengths $\left(C_{1}\right.$ to $\left.C_{5}\right)$. (B) Dose-dependent responses of the wild-type (WT) strain to increasing concentrations of ethanol. (C) Responses of adaptation-deficient mutants to ethanol and asparagine. (D) Responses of mutants expressing single chemoreceptors to ethanol. (E) Responses of mutants lacking key chemoreceptors to ethanol. (F) Responses of mutants expressing McpB or HemAT as their sole chemoreceptor to short-chain alcohols. In these experiments, ethanol and asparagine concentrations within the capillaries were $1.78 \mathrm{M}$ and $3.16 \mu \mathrm{M}$, respectively, unless otherwise mentioned. The negativecontrol responses of the strains expressing a single chemoreceptor to buffer were all $<100$ colonies per capillary. Error bars denote the standard deviations from three biological replicates performed on three separate days.

in the $\Delta c h e C$ and $\Delta c h e V$ mutants, although the reduction was less than what was observed with the double mutant. Interestingly, the CheC/CheD/CheYp system appears to be more important for sensing ethanol gradients than for sensing asparagine gradients (Fig. 1C). We did not test a $\Delta$ cheR $\Delta c h e B$ mutant, which lacks the two enzymes involved in the methylation system, because these mutants exhibit poor motility in general due to excessive tumbling.

McpB and HemAT are the chemoreceptors for short-chain alcohols. B. subtilis has 10 chemoreceptors (23). To determine the chemoreceptors involved in ethanol taxis, we first used the capillary assay to test mutants expressing just one chemoreceptor $(19,24,25)$. Only strains expressing McpB or HemAT as their sole chemoreceptor were capable of ethanol taxis (Fig. 1D). The response was greater for strains expressing HemAT, suggesting that it is the main receptor for ethanol taxis. This is not surprising, as HemAT is more highly expressed than McpB (19,000 copies versus 6,200 copies) (23). We next tested the effect of deleting these chemoreceptors in the wild type. When either $\mathrm{McpB}$ or HemAT was deleted $(\triangle m c p B$ or $\triangle$ hemAT), we observed reduced taxis toward ethanol. The reduction was greater in the $\triangle$ hemAT mutant, again suggesting that HemAT is the main receptor for ethanol taxis. When both chemoreceptors were deleted in the wild type $(\triangle m c p B \triangle h e m A T)$, ethanol taxis was almost eliminated, whereas the mutant exhibited a normal response to proline, an amino acid attractant sensed by $\mathrm{McpC}(1,138.7 \pm 34.6$ cells versus 1,276.9 \pm 54.1 cells for the wild type) (Fig. 1E). We also found that strains expressing $\mathrm{McpB}$ or HemAT as their sole chemoreceptor responded to methanol, 2-propanol, and tert-butanol (Fig. 1F). Strains expressing HemAT as their sole chemoreceptor exhibited stronger responses to these alcohols than strains expressing $\mathrm{McpB}$ alone, with the exception of 2-propanol, where the responses were similar. 


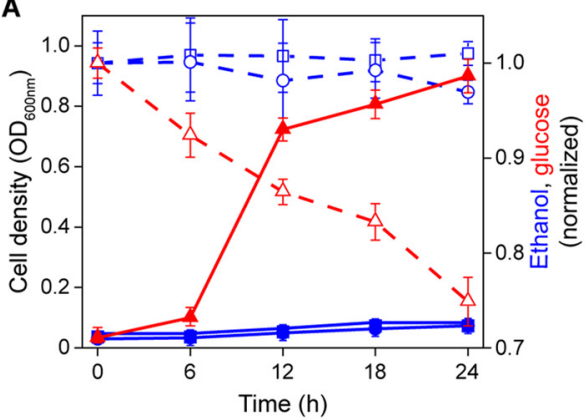

\begin{tabular}{l}
$\longrightarrow-$ Cell density-EtOH $(10 \mathrm{mM})$ \\
$\rightarrow-$ Cell density-EtOH $(100 \mathrm{mM})$ \\
$-\_$Cell density-Glu $(5 \mathrm{~g} / \mathrm{L})$ \\
$-\mathrm{O}-$ Norm. conc.-EtOH $(10 \mathrm{mM})$ \\
$-\square-$ Norm. conc.-EtOH $(100 \mathrm{mM})$ \\
$-\triangle-$ Norm. conc.-Glu $(5 \mathrm{~g} / \mathrm{L})$ \\
\hline
\end{tabular}

B
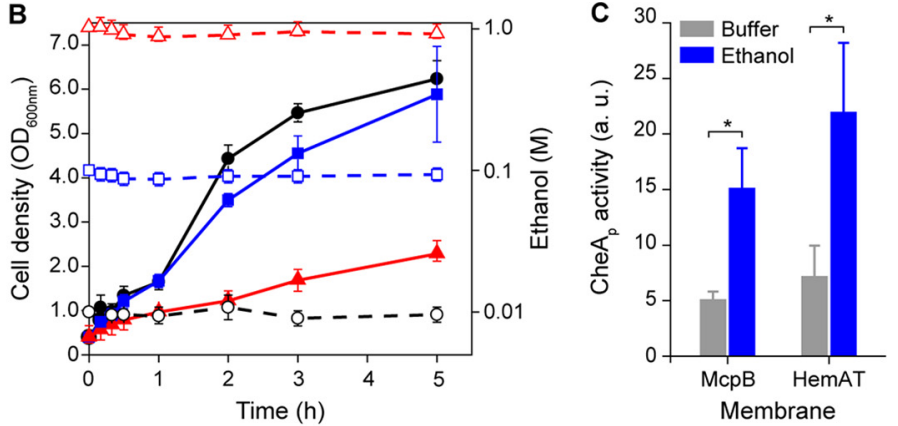

FIG 2 B. subtilis chemotaxis to ethanol is independent of its metabolism. (A) Cell growth in minimal medium supplemented with 10 mM ethanol (EtOH), $100 \mathrm{mM}$ ethanol, and $5 \mathrm{~g} /$ liter glucose tested as a positive control. Dashed lines with the corresponding symbols depict normalized concentrations of the chemicals measured over the course of $24 \mathrm{~h}$. (B) Cell growth in rich medium containing $10 \mathrm{mM}$ ethanol, $100 \mathrm{mM}$ ethanol, and $1 \mathrm{M}$ ethanol. Dashed lines with open symbols depict absolute concentrations of ethanol measured under three different conditions over the course of 5 h. (C) Levels of phosphorylated CheA kinase complexed with CheW, CheD, and McpB or HemAT within the isolated membranes, in the presence of $1 \mathrm{M}$ ethanol or buffer, as a negative control. Error bars denote the standard deviations from three biological replicates performed on three separate days. a.u., arbitrary units. ${ }^{*}, P<0.05$ (two-sided $t$ test [correction for unequal variances was applied]).

Chemotaxis to ethanol is independent of its metabolism. Many bacteria metabolize ethanol (26). One possibility is that B. subtilis senses products of ethanol metabolism rather than ethanol itself. Indeed, such a mechanism occurs in Pseudomonas putida with regard to alcohol taxis (27). Therefore, we tested whether B. subtilis can grow on ethanol (Fig. 2A). These growth experiments were performed using the parental strain $B$. subtilis 168 , which lacks the auxotrophies present in the chemotaxis strain Ol1085. When cells were cultured in minimal medium with ethanol as the sole carbon source, no growth was observed. However, the cells grew when ethanol was replaced with glucose. We also tested $B$. subtilis 168 growth in rich medium containing different amounts of ethanol to determine whether the cells were able to consume ethanol even though it does not support growth as the sole carbon source. While the cells were able to grow in rich medium containing ethanol, no decreases in ethanol concentrations were observed (Fig. 2B). These results indicate that $B$. subtilis does not consume ethanol.

The oxidation of alcohols to aldehydes and subsequently to carboxylic acids can potentially change the redox state of the cells. This change could be perceived as a sensory signal through a process known as energy taxis (28). B. subtilis can ferment glucose to acetate and ethanol when grown in the presence of pyruvate or a mixture of amino acids $(29,30)$. In this process, alcohol dehydrogenase (ADH) reduces acetaldehyde to ethanol using $\mathrm{NADH}$ as the cofactor. Whether $\mathrm{ADH}$ can oxidize ethanol to acetaldehyde in B. subtilis is unknown. To test whether this occurs, we measured ADH activities using $B$. subtilis cell lysates prepared from aerobic and anaerobic cultures. As a positive control, $\mathrm{ADH}$ activities using $E$. coli cell lysates were also measured (31). No $\mathrm{ADH}$ activity was observed with $B$. subtilis lysates, whereas $E$. coli lysates obtained from anaerobic cultures had an $\mathrm{ADH}$ activity of $31.25 \pm 1.85 \mathrm{U} / \mathrm{ml}$. As expected, no ADH activity was detected with aerobic $E$. coli lysates. These results suggest that ethanol taxis in $B$. subtilis is independent of ethanol catabolism and is instead sensed directly by McpB and HemAT.

Ethanol induces receptor-coupled kinase activity. We next performed an in vitro receptor-coupled kinase assay to test whether ethanol is able to activate CheA kinase (32). This assay has been used to study how attractant binding to chemoreceptors 
A

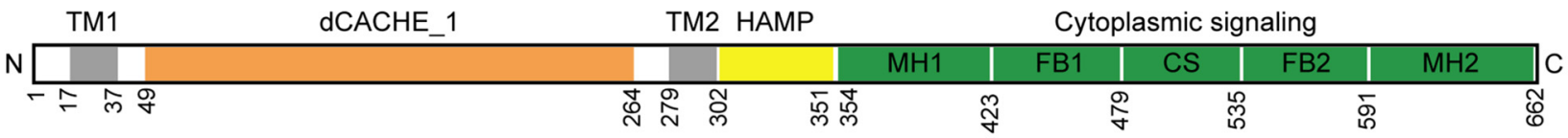

B

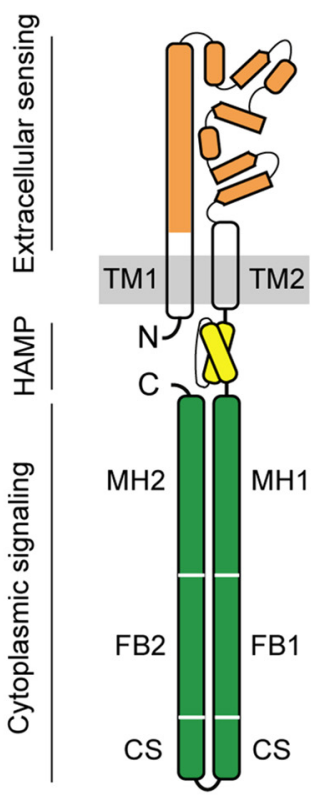

C

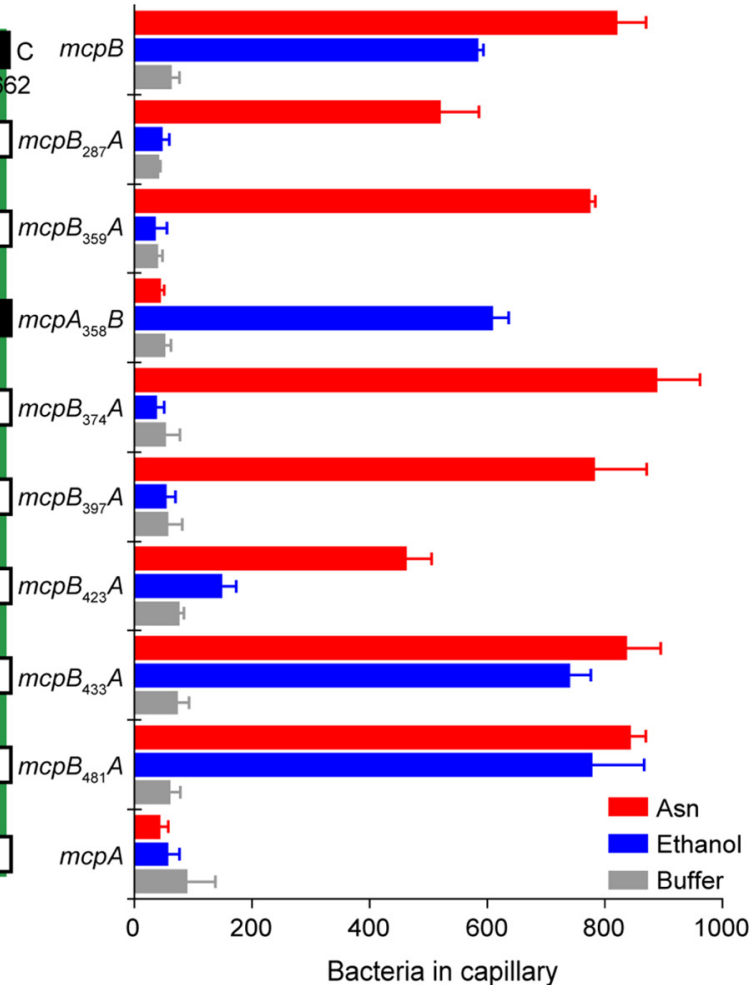

Receptor chimeras

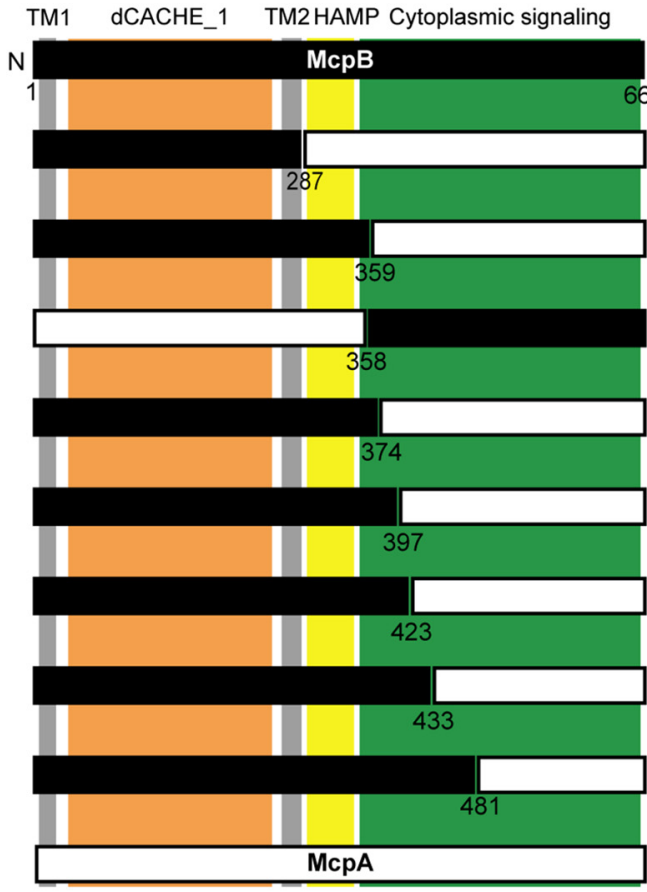

Bacteria in capillary

FIG 3 The McpB cytoplasmic signaling domain is involved in ethanol sensing. (A) Domain structures of McpB, McpA, TlpA, and TlpB. All four chemoreceptors consist of an extracellular sensing domain with a dCACHE 1 structure (orange) followed by transmembrane (TM1 and TM2) (gray), HAMP (yellow), and cytoplasmic signaling (green) domains. Three subdomains of the cytoplasmic signaling domain, classified as methylation (adaptation) helices (MH), the flexible (coupling) bundle (FB), and the conserved signaling (CS) (protein contact region) tip, are shown. (B) Cartoon structure of a monomer of the chemoreceptors. (C) Responses of mutants expressing chimeric receptors between McpA (white) and McpB (black) to $1.78 \mathrm{M}$ ethanol, $3.16 \mu \mathrm{M}$ asparagine, and buffer. Error bars denote the standard deviations from three biological replicates performed on three separate days.

modulates CheA kinase activity $(22,32)$. Briefly, membranes expressing either McpB or HemAT were isolated. The chemotaxis signaling proteins CheA, CheW, and CheD were then added to these membranes to final concentrations that matched their stoichiometry in wild-type cells. Using this assay, we found that ethanol activates CheA kinase in a dose-dependent manner with membranes containing either McpB or HemAT as the sole chemoreceptor. Ethanol concentrations as low as $10 \mathrm{mM}$ were sufficient to activate CheA kinase in both cases (Fig. 2C; see also Fig. S1 in the supplemental material). These results indicate that ethanol can induce chemotaxis signaling in vitro. This assay, however, is unable to determine whether ethanol directly interacts with the chemoreceptors because the membranes might contain associated proteins that could be involved in signaling.

The McpB cytoplasmic signaling domain is involved in ethanol sensing. We next investigated ethanol taxis using receptor chimeras involving $\mathrm{McpB}$ to provide further insight regarding the sensing mechanism $(25,33,34)$. We focused on McpB due to its high amino acid similarity (57\% to $65 \%$ ) with three other $B$. subtilis chemoreceptors: McpA, TIpA, and TIpB. These four chemoreceptors all employ the same double Cache 1 sensing domain (2) and a highly conserved coiled-coil structure for their cytoplasmic signaling domain (10) (Fig. 3A and B). Unlike McpB, HemAT is not a transmembrane chemoreceptor. We attempted to construct chi- 
meras involving HemAT, McpA, and YfmS, another soluble chemoreceptor. However, none were functional in the sense that they did not respond to ethanol or molecular oxygen, which is the conventional attractant for HemAT (24).

We created chimeras between $\mathrm{McpB}$ and McpA because the latter is not involved in ethanol taxis. In addition, we measured the response to asparagine because it is a known attractant for $\mathrm{McpB}$, but not McpA, and it binds the extracellular sensing domain (18). We first fused the $\mathrm{N}$-terminal region of $\mathrm{McpB}$ to the C-terminal region of McpA: $m c p B_{287} A$ and $m c p B_{359} A$. We then tested whether strains expressing these chimeras as their sole chemoreceptor respond to ethanol using the capillary assay. Both mutants failed to respond to ethanol even though they still responded to asparagine (Fig. $3 \mathrm{C}$ ). These results demonstrate that the extracellular sensing and cytoplasmic HAMP domains are not involved in sensing ethanol. Rather, the cytoplasmic signaling domain is involved. To verify our hypothesis, we tested an $m c p A_{358} B$ chimera. As expected, a strain expressing $m c p A_{358} B$ as its sole chemoreceptor responded to ethanol. This strain, however, does not respond to asparagine because it lacks the requisite McpB sensing domain (Fig. 3C).

Key features of chemoreceptor cytoplasmic signaling domains are the characteristic heptad repeats (labeled $a$ to $g$ ) associated with their coiled-coil structure, where each repeat is equivalent to two helical turns. Based on sequence conservation and structural analyses of heptads from several bacterial and archaeal chemoreceptors, the cytoplasmic signaling domains are classified into three structurally distinct subdomains. These subdomains are known as the methylation (adaptation) helices, the flexible (coupling) bundle, and the conserved signaling tip (protein contact region) (10) (Fig. 3 and Fig. S2). To narrow down the region of these subdomains involved in ethanol sensing, we created $m c p B_{374} A, m c p B_{397} A, m c p B_{423} A, m c p B_{433} A$, and $m c p B_{481} A$ chimeras. Strains expressing $m c p B_{374} A$ and $m c p B_{397} A$ as their sole chemoreceptor did not respond to ethanol even though they still responded to asparagine. Strains expressing $\operatorname{mcp}_{4}{ }_{423} A$ as their sole chemoreceptor exhibited a reduced response to ethanol and asparagine. However, when $m c p B_{433} A$ and $m c p B_{481} A$ were tested, the strains expressing these chimeras were able to respond to ethanol and asparagine at levels similar to those of the wild-type control (Fig. 3C). These results suggest that the region spanning residues 397 to 433 on $\mathrm{McpB}$ is involved in sensing ethanol. Furthermore, the region spanning residues 423 to 433 on $M c p B$ appears to be the principal region involved in ethanol sensing.

An McpB residue involved in ethanol sensing. The region spanning residues 397 to 433 on $\mathrm{McpB}$ is necessary for ethanol taxis. As a first step toward identifying the binding site, we performed in silico docking experiments with ethanol and the McpB dimer fragment spanning residues 390 to 435 on the N-helix and the neighboring residues 577 to 622 on the $\mathrm{C}$-helix. The resulting data from the docking analysis yielded five distinct clusters of putative amino acid residues involving both the $\mathrm{N}$-helix and the C-helix of the dimer fragment (Table S1 and Fig. S3A). We next aligned the amino acid sequences spanning residues 392 to 434 on the $\mathrm{N}$-helix and the neighboring residues 578 to 620 on the C-helix of McpB, McpA, TlpA, and TlpB (Fig. S3B). Among the 20 putative binding residues, $\mathrm{Thr}^{424}, \mathrm{Asp}^{427}$, and $\mathrm{Ala}^{431}$ on the N-helix and $\mathrm{Glu}^{581}$ and Lys $^{585}$ on the C-helix were not conserved between the four chemoreceptors and, thus, were targeted for mutational analysis (Fig. 4A and B). Mutants expressing McpB-T424A, McpB-D427T, McpB-E581Q, and McpB-K585E as their sole chemoreceptor exhibited responses to ethanol similar to those of wild-type $m c p B$. However, the strain expressing McpB-A431S as its sole chemoreceptor failed to respond to ethanol. In addition, all strains supported asparagine taxis, indicating that these mutated receptors were functional (Fig. 4C). We also measured the responses of the strain expressing McpBA431S to methanol, 2-proponal, and tert-butanol in the capillary assay and observed reduced responses (Fig. 4D), suggesting that $\mathrm{Ala}^{431}$ is an important residue for alcohol taxis overall. 
A

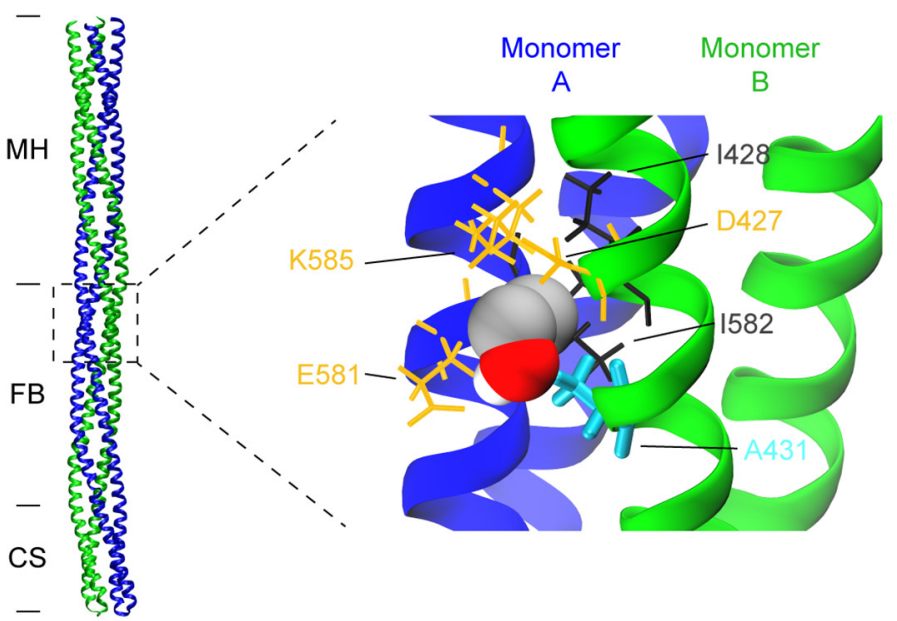

B

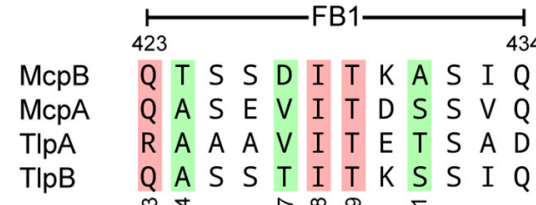

N-helix

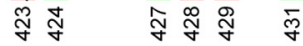

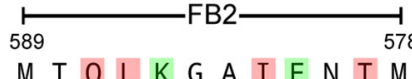

McpB $\quad$ M T Q L K G A I E N T M

McpA $M N$ Q L E G A I Q N T M

TIpA $\quad M N$ N L E S A I Q N

TIpB L N Q L E G S I Q T T T M

C-helix

C

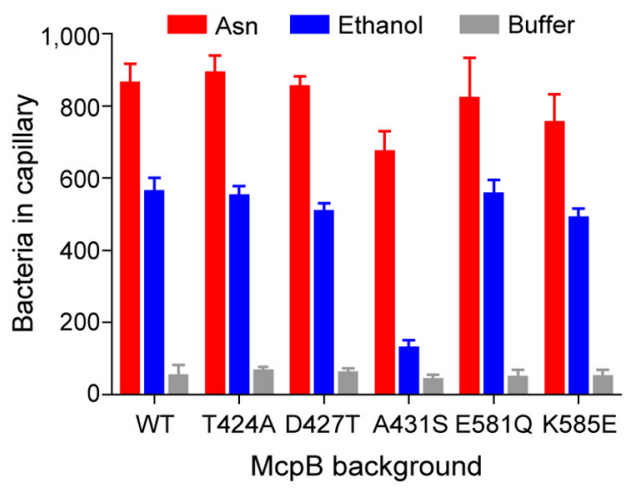

F

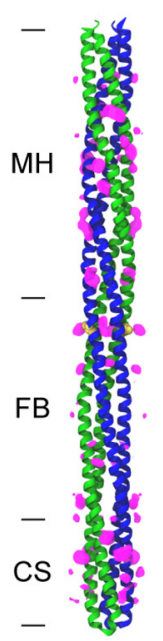

D

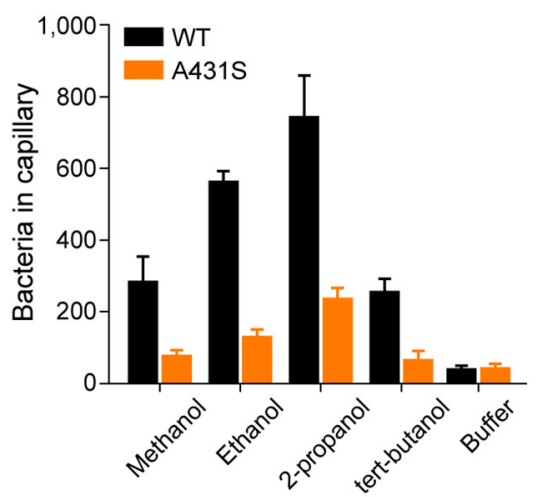

$\mathbf{H}$
E

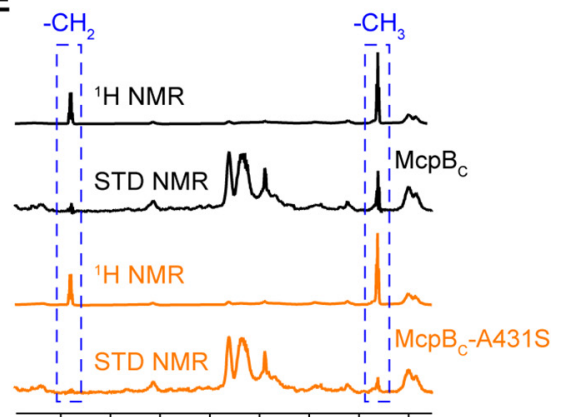

$\begin{array}{llllllll}3.6 & 3.2 & 2.8 & 2.4 & 2.0 & 1.6 & 1.2 & 0.8\end{array}$

Chemical shift (ppm)
G
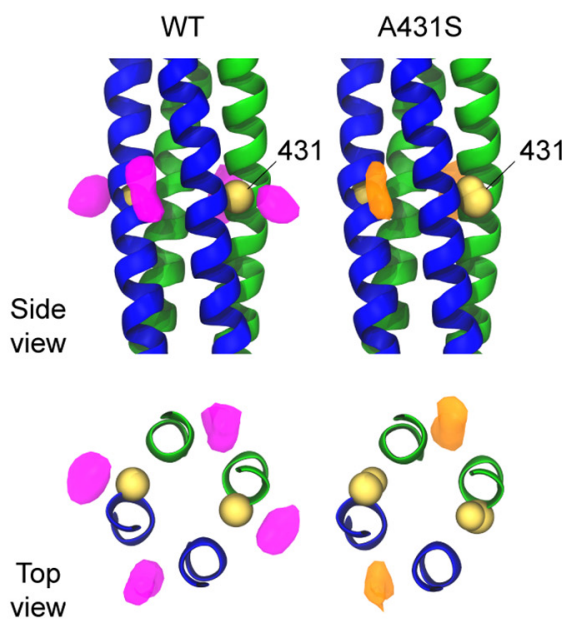
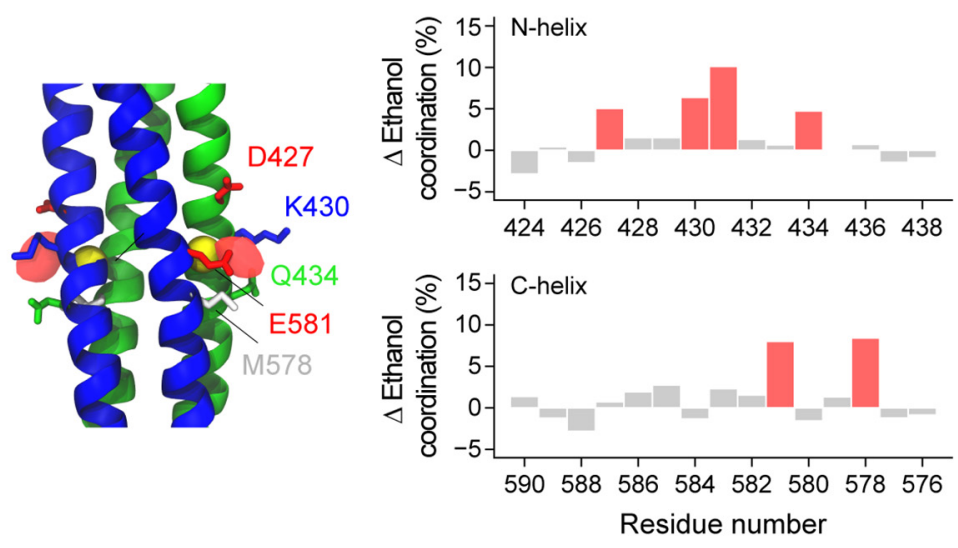

FIG 4 Alcohols are directly sensed by the cytoplasmic signaling domain of McpB. (A) Putative binding site within the primary ethanol-sensing region spanning residues 423 to 433 on the $\mathrm{N}$-helix and the neighboring residues 579 to 589 on the C-helix of the McpB cytoplasmic signaling domain. (B) Amino acid sequence alignment of the primary ethanol-sensing region for $\mathrm{McpB}$ and the corresponding regions on Mcp A, TlpA, and TlpB. (C) Responses of strains expressing McpB mutants as their sole chemoreceptor to $1.78 \mathrm{M}$ ethanol, $3.16 \mu \mathrm{M}$ asparagine, and buffer. (D) Responses of strains expressing wild-type McpB and the McpB-A431S mutant as their sole chemoreceptor to $1.78 \mathrm{M}$ short-chain alcohols and buffer. (E) ${ }^{1} \mathrm{H}$ and STD-NMR spectra for $50 \mu \mathrm{M}$ wild-type and mutant (A431S) recombinant $\mathrm{McpB}$ cytoplasmic regions $\left(\mathrm{McpB}_{\mathrm{C}}\right.$ ) spanning residues 305 to 662 . Two peaks at $1.05 \mathrm{ppm}$ and $3.51 \mathrm{ppm}$ (shown inside dashed boxes) correspond to $-\mathrm{CH}_{3}$ and $-\mathrm{CH}_{2}$ epitopes of ethanol, respectively. (F) Density map of the average ethanol occupancy (purple) along the wild-type McpB cytoplasmic signaling domain $\left(\mathrm{McpB}_{\mathrm{C}}\right)$ spanning residues 352 to 662 , as predicted by $M D$ simulation. (G) Enlarged side and top views of the ethanol occupancy surrounding residue

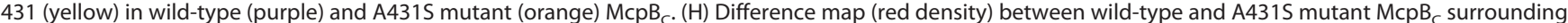
residue 431 highlighting the loss of an intermonomer ethanol-binding site in the A431S mutant. Changes in protein-ethanol coordination highlight the putative amino acid residues (red bars) involved in ethanol binding. Error bars reported in panels $C$ and $D$ denote the standard deviations from three biological replicates performed on three separate days. Ethanol occupancy and coordination values were generated from three independent MD simulations. 
Ethanol directly binds to the MсрB cytoplasmic signaling domain. To test whether ethanol directly interacts with $\mathrm{McpB}$, we conducted saturation transfer difference nuclear magnetic resonance (STD-NMR) experiments using recombinant McpB. STD-NMR has been used to measure weak interactions between proteins and their ligands (35-38). Briefly, in these experiments, the protein is selectively saturated at specific frequencies. The magnetization is then transferred to the surrounding, lowmolecular-weight ligands in a distance-dependent manner. The ligand epitopes near the protein receive higher saturation (39), implying direct binding to the protein.

We first tested the $\mathrm{McpB}$ cytoplasmic region $\left(\mathrm{McpB}_{\mathrm{C}}\right)$ spanning residues 305 to 662 , which corresponds to the HAMP and signaling domains (Fig. 3A). The resulting ${ }^{1} \mathrm{H}$ spectrum for the $\mathrm{McpB}_{\mathrm{C}}$ protein incubated with $3 \mathrm{mM}$ ethanol (60-fold molar excess of the protein) is shown in Fig. 4E. Two peaks for ethanol appeared near $1.05 \mathrm{ppm}$ and $3.51 \mathrm{ppm}$, which correspond to the $-\mathrm{CH}_{3}$ and $-\mathrm{CH}_{2}$ epitopes of ethanol, respectively. Ligand signals were also observed at the expected chemical shift values ( $1.05 \mathrm{ppm}$ and $3.51 \mathrm{ppm}$ ) on the STD spectra. Additionally, the area under the STD peak corresponding to the $-\mathrm{CH}_{2}$ epitope was about 5 -fold (18\%) smaller than that of the $-\mathrm{CH}_{3}$ epitope (Fig. 4E), suggesting that the $-\mathrm{CH}_{3}$ moiety of ethanol is closer to the protein than its $-\mathrm{CH}_{2}$ moiety. Moreover, control experiments using $3 \mathrm{mM}$ 1-pentanol, which is not an attractant, and $\mathrm{McpB}_{\mathrm{C}}$ showed negligible STD peaks near the characteristic chemical shift values $(3.5,1.41,1.18$, and $0.8 \mathrm{ppm})$, suggesting that 1-pentanol does not bind $\mathrm{McpB}_{\mathrm{C}}$ (Fig. S4A). As an additional negative control, we performed STD-NMR experiments using the McpA cytoplasmic region spanning residues 305 to 661 with $3 \mathrm{mM}$ ethanol. Consistent with our in vivo results, we did not observe significant STD peaks near the characteristic chemical shift values (Fig. S4A). These results collectively indicate that ethanol directly interacts with the McpB cytoplasmic region.

Strains expressing McpB-A431S as their sole chemoreceptor exhibited a reduced response to ethanol when tested in the capillary assay (Fig. 4C). To determine whether the A431S mutation reduces ethanol binding, we repeated the STD-NMR experiments with the recombinant $\mathrm{McpB}_{C}-\mathrm{A} 431 \mathrm{~S}$ protein. Because single mutations may impair the proper folding of proteins, we first measured the circular dichroism (CD) spectra for both the wild-type $\mathrm{McpB}_{C}$ and the $\mathrm{McpB}_{C}-\mathrm{A} 431 \mathrm{~S}$ proteins. We observed similar spectra for both proteins, which suggests that the mutant protein preserves the wild-type helical structure (Fig. S4B). We then performed STD-NMR experiments with $\mathrm{McpB}_{\mathrm{C}^{-}}$ A431S in the presence of $3 \mathrm{mM}$ ethanol. The resulting STD spectra showed reduced peaks near $1.05 \mathrm{ppm}$ and $3.51 \mathrm{ppm}$ compared to wild-type $\mathrm{McpB}_{\mathrm{C}}$ (Fig. 4E). The saturation fractions of ethanol, which correspond to the ratios of the areas under the respective $-\mathrm{CH}_{3}$ peaks on STD and ${ }^{1} \mathrm{H}$ spectra, are 0.23 for $\mathrm{McpB}_{\mathrm{C}}$ and 0.1 for $\mathrm{McpB}_{\mathrm{C}^{-}}$ A431S. These results imply that residue $\mathrm{Ala}^{431}$ has a role in ethanol binding to the $\mathrm{McpB}$ signaling domain.

Molecular dynamics simulation suggests the A431S mutation reduces the affinity of ethanol for the McpB cytoplasmic signaling domain. To gain insight regarding the ethanol-binding mechanism, we performed molecular dynamics (MD) simulations of the wild-type and A431S McpB cytoplasmic signaling dimers (residues 352 to 662) in the presence of ethanol. Our simulations demonstrate that ethanol can bind nonspecifically throughout the cytoplasmic signaling domain in both the wildtype and mutant $\mathrm{McpB}$ dimers, primarily interacting along the interhelical grooves of the four-helix bundle (Fig. 4F and Fig. S5A). A comparison of ethanol occupancies between wild-type and A431S mutant $\mathrm{McpB}$ showed little variation overall but exhibited a marked difference in the region immediately surrounding residue 431 . In particular, while ethanol was observed to bind at both the inter- and intramonomer interfaces in the wild-type simulations, the intermonomer binding site associated with the residue 431 side chain was not present in the mutant simulations (Fig. 4G), suggesting that the A431S mutation reduces the binding affinity of ethanol. Indeed, within the flexible-bundle region, the residues displaying the greatest change in 
ethanol coordination between the wild type and the A431S mutant form a concentric pocket centered on residue 431 at the intermonomer interface (Fig. $4 \mathrm{H}$ ).

Our analyses identified another interesting feature of ethanol binding, namely, that it is able to penetrate the surface of the McpB cytoplasmic domain to bind within the core of the coiled coil. In particular, we observed that ethanol entered between the individual helices of the four-helix bundle at two locations in the methylation-helix region: one involving N-helix residues 393 to 400 and C-helix residues 613 to 617 and the other involving $\mathrm{N}$-helix residues 382 to 387 and C-helix residues 628 to 631 (Fig. S5A). While ethanol binding to these regions was observed in both the wild-type and A431S mutant simulations, the wild-type binding events resulted in longer dwell times, giving rise to the difference in ethanol coordination observed in these regions (Fig. S5A). Preliminary analysis of the two sites, however, suggests that they do not themselves play a significant role in signaling. The latter is located outside the region involved in ethanol sensing (Fig. 3C), and the former, except for residue Glü399, is highly conserved among the four chemoreceptors (Fig. S3B). Indeed, we did not observe a significant reduction in response to ethanol compared to the wild-type control when we tested a mutant expressing McpB-E399K as its sole chemoreceptor in the capillary assay (569 \pm 29.1 cells versus $586.1 \pm 9.0$ cells, respectively). Nevertheless, these observations hint at a signaling mechanism in which ethanol may penetrate to the core of the cytoplasmic domain, where it can affect the packing and overall stability of the bundle.

To investigate the above-described packing hypothesis further, we analyzed the strength of knobs-in-holes interactions in the region surrounding residue 431 over the course of the simulations. We observed that the A431S mutation leads to an increased occupancy of the residue 431 knob itself as well as nearby knobs on the C-helix at positions 583 and 585 (Fig. S5B), indicating stronger hydrophobic interactions between the individual helices. Therefore, our simulation results suggest that the A431S substitution, which decreases the $M c p B$ ethanol response, not only reduces the direct binding of ethanol but also strengthens coiled-coil packing in the region. One possibility is that the reduced local concentration of ethanol and improved packing in the A431S mutant decrease the ability of ethanol to intercalate with the knobs-into-holes interactions near residue 431 and, thus, its ability to induce signaling.

The HemAT sensing domain helices are directly involved in ethanol sensing. HemAT is a cytoplasmic chemoreceptor that consists of an N-terminal sensing domain and a C-terminal signaling domain. To determine whether the HemAT signaling domain is also involved in ethanol sensing, we conducted STD-NMR experiments with the purified signaling domain (HemATs), spanning residues 177 to 432 , and the purified sensing domain $\left(\operatorname{HemAT}_{N}\right.$ ), spanning residues 1 to 178 , of HemAT in the presence of $3 \mathrm{mM}$ ethanol. The STD spectra with the HemAT signaling domain showed negligible peaks near the expected chemical shift values (1.05 ppm and $3.51 \mathrm{ppm})$, while the resulting ${ }^{1} \mathrm{H}$ and STD spectra with $\mathrm{HemAT}_{\mathrm{N}}$ showed clear peaks near $1.05 \mathrm{ppm}$ and $3.51 \mathrm{ppm}$, which correspond to the $-\mathrm{CH}_{3}$ and the $-\mathrm{CH}_{2}$ moieties of ethanol. The ratios of the areas in the STD spectra to those in the ${ }^{1} \mathrm{H}$ spectra were 0.27 for the $-\mathrm{CH}_{3}$ moiety and 0.85 for the $-\mathrm{CH}_{2}$ moiety, suggesting that the $-\mathrm{CH}_{2}$ moiety of ethanol is closer to the protein than its $-\mathrm{CH}_{3}$ moiety (Fig. 5A). These results collectively indicate that ethanol binds the sensing domain of HemAT.

The sensing domain of the HemAT dimer is composed of a four-helical bundle as its core and a heme group in each subunit (Fig. 5B), which is known to bind molecular oxygen (40). UV spectral analyses have shown that the oxygen molecule binds the heme group by forming hydrogen bonds with 6-coordinate ferrous heme $(41,42)$. To determine whether the heme group also interacts with ethanol, we conducted UV spectroscopy experiments with the purified HemAT sensing domain (HemAT ${ }_{N}$ ) and ethanol. As a control, we first measured the UV absorption of both oxygenated and deoxygenated forms of the protein to verify that the heme group on the purified protein is functional. Consistent with previous reports $(24,41,43)$, the oxygenated form of HemAT ${ }_{N}$ exhibited three major canonical peaks at $412 \mathrm{~nm}$ (Soret), $544 \mathrm{~nm}$ ( $\beta$-band), 


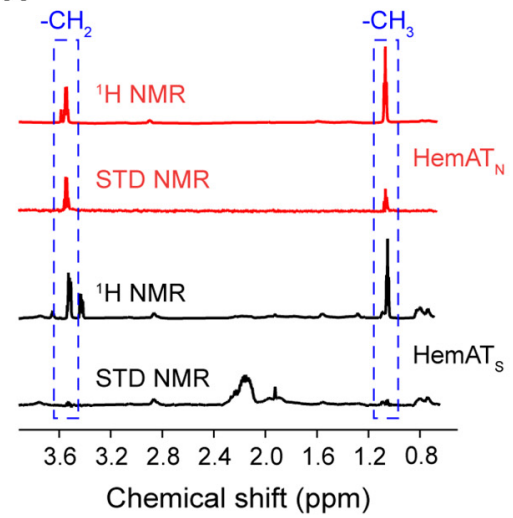

B

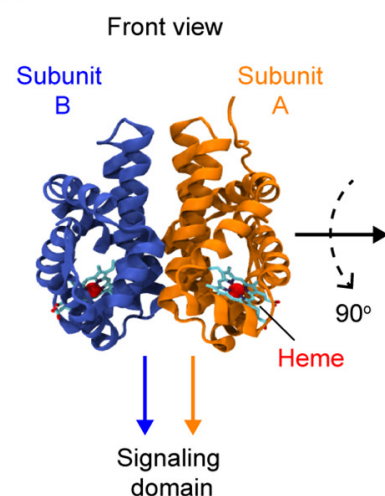

C

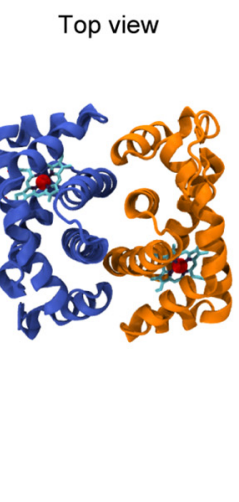

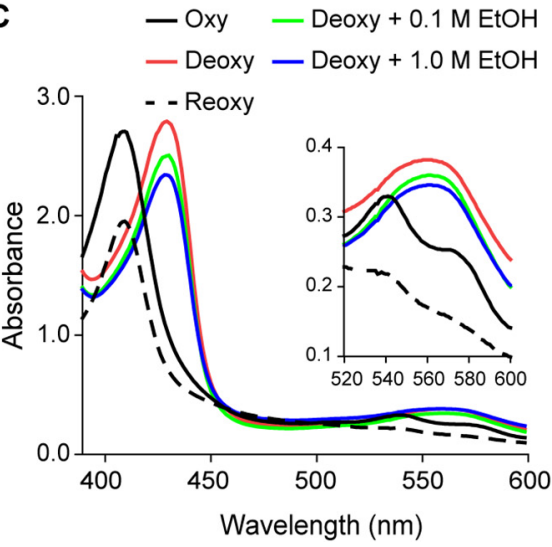

FIG 5 Ethanol directly binds within the helices of the HemAT sensing domain. (A) ${ }^{1} \mathrm{H}$ and STD-NMR spectra for $50 \mu \mathrm{M}$ the recombinant HemAT C-terminal signaling domain (HemATs) spanning residues 177 to 432 and for $50 \mu \mathrm{M}$ the recombinant HemAT N-terminal sensing domain (HemAT s $_{\mathrm{S}}$ spanning residues 1

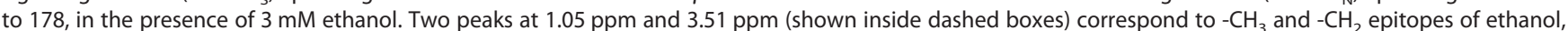

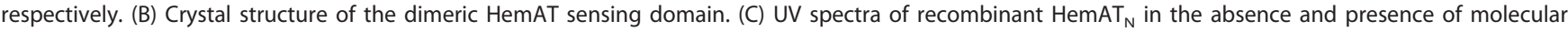
oxygen, $0.1 \mathrm{M}$ ethanol, and $1.0 \mathrm{M}$ ethanol.

and $578 \mathrm{~nm}$ ( $\alpha$-band), and the dithionite-reduced deoxygenated form of the protein exhibited two major peaks at $434 \mathrm{~nm}$ and $556 \mathrm{~nm}$ (Fig. 5C). Next, we measured the UV absorption of the deoxygenated HemAT sensing domain in the presence of various concentrations of ethanol. The resulting spectra showed two major peaks at $434 \mathrm{~nm}$ and $556 \mathrm{~nm}$, similar to what we observed with the deoxygenated form of the protein in the absence of any ligand (Fig. 5C). These results imply that the heme group does not interact with ethanol. Rather, they suggest that ethanol binds to the alpha helices of the HemAT sensing domain. It is noteworthy that while ethanol binds to the alpha helices in both McpB and HemAT, the binding mode appears to be different. The STD-NMR experiments suggest that the $-\mathrm{CH}_{3}$ moiety of ethanol is closer to $\mathrm{McpB}$ than its $-\mathrm{CH}_{2}$ moiety, whereas the ethanol binding direction is reversed in the case of HemAT.

\section{DISCUSSION}

We found that $B$. subtilis performs chemotaxis to multiple short-chain alcohols. These alcohols are directly sensed by two chemoreceptors, McpB and HemAT. McpB is a transmembrane chemoreceptor with an extracellular sensing domain and a cytoplasmic signaling domain, which are linked by a cytoplasmic HAMP domain. It is known to sense the amino acid asparagine and alkaline environments as attractants using the extracellular sensing domain $(18,25)$. HemAT, on the other hand, is a soluble chemoreceptor that consists of a sensing and a signaling domain but lacks a HAMP domain. Its myoglobin-like sensing domain contains heme and is known to bind molecular oxygen $(24,42)$. Using chimeric receptors and STD-NMR, we found that short-chain alcohols are directly sensed by the cytoplasmic signaling domain of McpB and the sensing domain of HemAT. In the case of HemAT, the alcohols do not appear to bind heme; rather, they likely bind between the helices encapsulating the heme.

Among the alcohols tested, ethanol is the most likely physiological attractant because it is produced by many microorganisms and is prevalent in nature (17). As a consequence, we focused on this chemical. Curiously, ethanol is not consumed by $B$. subtilis, suggesting that it is used for purposes other than nutrition. One possibility is that $B$. subtilis uses ethanol to locate prey, which could explain why $B$. subtilis is attracted to a chemical that nominally inhibits its growth. The most likely prey are Crabtree-positive yeast such as Saccharomyces cerevisiae, which produces ethanol at high concentrations even during aerobic growth (44). Indeed, B. subtilis can lyse $S$. cerevisiae cells through the production of cell wall-degrading compounds (see Fig. S6 in the supplemental material) (45-47).

Aside from ethanol, methanol may also be a physiological attractant. It is a byproduct of pectin degradation and, as a consequence, can contaminate alcoholic 
beverages (48). However, B. subtilis does not consume methanol because it lacks methanol dehydrogenase activity (49). Similar to ethanol, $B$. subtilis may use methanol to locate prey, in this case pectin-degrading microorganisms.

These speculations are in line with the results from a previous study where no correlation was observed between the metabolic and chemotactic preferences of $B$. subtilis for amino acids (50). That study proposed that $B$. subtilis uses amino acid gradients as cues to locate sources of nutrients, for example, during plant root colonization $(50,51)$. The only other bacterium known to exhibit taxis toward alcohols is Pseudomonas putida (27). However, this bacterium consumes alcohols. In addition, it does not directly sense these alcohols but rather senses the by-products of their degradation, namely, carboxylic acid. Finally, alcohol taxis is also observed in E. coli and Ralstonia pseudosolanacearum. In these bacteria, however, alcohols are sensed as repellents $(52,53)$.

A key difference between taxis to alcohols and conventional attractants such as amino acids is their respective sensitivities. Amino acids are sensed at micromolar concentrations, whereas alcohols are sensed at millimolar concentrations. However, it should be noted that while low millimolar concentrations (e.g., $3 \mathrm{mM}$ ) of ethanol can bind $\mathrm{McpB}$ and HemAT in vitro, much higher ethanol levels are required for optimal chemotaxis in the capillary assay experiments. The disparity may be due to the architecture of the capillary assay. Briefly, chemotaxis to ethanol occurs when ethanol concentrations in the capillaries are as low as $50 \mathrm{mM}(190.1 \pm 44.5$ cells versus $42.3 \pm 6.2$ cells for buffer), and the response to ethanol peaks when capillaries contain about $2 \mathrm{M}$ ethanol. These concentrations, however, do not reflect the ethanol concentrations that cells experience near the mouth of the capillary in the pond. Three-dimensional simulations based on finite-element analysis of ethanol diffusion from a capillary into a pond indicate that the ethanol concentration falls dramatically, 10 to 50 times, compared with the initial ethanol concentration in the capillary near the mouth of the capillary (distances of $<0.5 \mathrm{~mm}$ ) (Fig. S7). These simulation results suggest that cells are able to respond to ethanol levels ranging from 1 to $200 \mathrm{mM}$. That said, the weak affinity for alcohols is not surprising because most ethanol receptors in mammals also exhibit a weak affinity for ethanol (54).

The question, then, is whether ethanol is actually an attractant for $B$. subtilis given that relatively high concentrations are necessary to elicit taxis. Overripe fruits provide one potential source for high ethanol concentrations, where concentrations can exceed $1 \mathrm{M}$ (55). In addition, flooded plant roots can provide another source at millimolar concentrations (56-58). In this case, B. subtilis perhaps uses ethanol to locate roots for colonization to initiate symbiosis (51). These observations suggest that ethanol taxis can indeed occur in the environment. Whether the other alcohols reach such concentrations in the environment is not known.

Perhaps the most interesting aspect of ethanol taxis involves the sensing mechanism. Typically, small-molecule attractants bind the extracellular sensing domain. The main exceptions are PTS sugars, which are sensed indirectly through the PTS system (5, 6). Ethanol is sensed intracellularly. In the case of HemAT, this distinction is minor, as ethanol binds the sensing domain albeit one normally associated with oxygen sensing. In the case of $\mathrm{McpB}$, the cytoplasmic signaling domain is involved in sensing ethanol through direct binding. This appears to be the first documented case of the cytoplasmic signaling domain being directly involved in sensing. While we were able to establish that ethanol binds the McpB cytoplasmic signaling domain using genetics and STDNMR, the details of the binding and signaling mechanisms are still somewhat opaque. In particular, it is not clear whether ethanol exerts its effect precisely at residue 431 or possibly at one or multiple other positions along the lengthy cytoplasmic domain. Molecular dynamics simulations suggest that ethanol can bind nonspecifically at several places on the McpB cytoplasmic surface as well as penetrate to the core of the four-helix bundle, at least within the methylation helix region. Although we did not observe ethanol entering the bundle core near residue 431 in our simulations, it may do so on longer time scales or in particular signaling states. In addition, precise 
molecular details of how ethanol binding induces signaling in wild-type McpB remain to be worked out. The enhanced packing interactions in McpB-A431S, which does not respond to ethanol, suggest that $A 431$ may disrupt or loosen packing, leading to changes in the overall stability of McpB that can be transmitted to the kinase. This idea is in line with numerous previous studies of the E. coli Tsr and Tar chemoreceptors, for example, that suggest that changes in periplasmic ligand binding and the adaptation state affect packing throughout the cytoplasmic bundle $(5,6)$.

Many aspects of ethanol sensing in B. subtilis are analogous to mechanisms observed in higher eukaryotes. Alcohols generally bind to proteins with low affinities, and relatively high concentrations of alcohols are required to induce behavioral effects. For example, ligand-gated ion channel receptors such as the $N$-methyl-D-aspartate (NMDA)type glutamate receptors, $\gamma$-aminobutyric acid type $A\left(G A B A_{A}\right)$ receptors, and glycine receptors all exhibit weak affinities for ethanol $(>10 \mathrm{mM})$ (54). Although the binding sites on these proteins are not well characterized, ethanol is thought to bind helical regions in most cases. In the case of the $\mathrm{GABA}_{\mathrm{A}}$ receptor, for example, ethanol binds within a small cavity between two transmembrane helices (TM2 and TM3) (59). Molecular dynamics studies show that ethanol modulates the receptor states by stabilizing helical crossing angles with a "wringing motion" $(60,61)$. Ethanol inhibition of the NMDA receptor is regulated by counteracting forces on $M 3$ helices of the receptors with additional interactions with side chains (62). Potassium channels are also affected by $>100 \mathrm{mM}$ ethanol concentrations. Kinetic and structural studies of Shaw $2 \mathrm{~K}^{+}$ channels have shown that the alpha-helical propensity of the loop in the pore-forming subunit is important for ethanol binding (63). Similarly, in the case of the odorantbinding protein LUSH from Drosophila melanogaster, a small cavity between the alpha helices accommodates a single ethanol molecule, whose hydroxyl group forms hydrogen bonds with neighboring threonine $\left(\mathrm{Thr}^{57}\right)$ and serine $\left(\mathrm{Ser}^{52}\right)$ residues (64). The binding motif found in LUSH is shared by the GABA receptor, the glycine receptor, and the Drosophila Shaw2 $\mathrm{K}^{+}$channel (64), suggesting a common alcohol-binding mechanism in eukaryotes.

Experimental and computational studies of the ion channel GLIC in the bacterium Gloeobacter violaceus also point to a mechanism of alcohol binding within cavities between transmembrane helices (65). Analysis of binding sites from structural studies suggests that ethanol preferentially binds helices with amphipathic surfaces $(54,66$, 67). The sensing mechanisms for these proteins typically involve the replacement of water molecules with ethanol within small hydrophobic cavities between two or more helices. Indeed, an analogous mechanism appears to be employed by the $B$. subtilis chemoreceptors. Given the reported similarities in the modes of action of ethanol in both prokaryotic and eukaryotic proteins, the model hypothesized in this investigation could provide evolutionary clues on the mechanisms of alcohol-sensing proteins.

\section{MATERIALS AND METHODS}

Chemicals and growth media. The following media were used for cell growth: Luria-Bertani (LB) broth ( $1 \%$ tryptone, $0.5 \%$ yeast extract, and $0.5 \% \mathrm{NaCl})$, tryptone broth (TB) ( $1 \%$ tryptone and $0.5 \%$ $\mathrm{NaCl})$, tryptose blood agar base (TBAB) ( $1 \%$ tryptone, $0.3 \%$ beef extract, $0.5 \% \mathrm{NaCl}$, and $1.5 \%$ agar), yeast-peptone-dextrose (YPD) broth ( $1 \%$ yeast extract, $2 \%$ peptone, and $2 \%$ dextrose), and capillary assay minimal medium (CAMM) $\left[50 \mathrm{mM}\right.$ potassium phosphate buffer $(\mathrm{pH} 7.0), 1.2 \mathrm{mM} \mathrm{MgCl}{ }_{2}$ $0.14 \mathrm{mM} \mathrm{CaCl}, 1 \mathrm{mM}\left(\mathrm{NH}_{4}\right)_{2} \mathrm{SO}_{4}, 0.01 \mathrm{mM} \mathrm{MnCl}$, and $42 \mu \mathrm{M}$ ferric citrate]. Chemotaxis buffer consists of $10 \mathrm{mM}$ potassium phosphate buffer $(\mathrm{pH} 7.0), 0.14 \mathrm{mM} \mathrm{CaCl}, 0.3 \mathrm{mM}\left(\mathrm{NH}_{4}\right)_{2} \mathrm{SO}_{4}, 0.1 \mathrm{mM}$ EDTA, $5 \mathrm{mM}$ sodium lactate, and $0.05 \%$ ( $\mathrm{vol} / \mathrm{vol}$ ) glycerol. All alcohols used in this study were purchased from Fisher Scientific, Inc.

Strains and plasmids. All strains and plasmids used in this work are listed in Tables 1 and 2, respectively. Chemotaxis experiments were performed with derivatives of $B$. subtilis Ol1085. Growth experiments were performed using $B$. subtilis 168 , which is the parental strain. The undomesticated $B$. subtilis strain NCBI 3610 and the Saccharomyces cerevisiae CEN.PK113-7D yeast strain were used in the antimicrobial diffusion assays. All cloning was performed using NEB 5-alpha competent E. coli (New England BioLabs). All oligonucleotides used in this study are provided in Table S2 in the supplemental material.

Gene deletions were constructed using plasmids derived from pJSpe, which provides a CRISPR/Cas9based, marker-free, and scarless genome-editing system for $B$. subtilis (68). To construct a deletion vector, a 20-bp CRISPR RNA target sequence complementary to the targeted gene sequence was designed using 
TABLE 1 Strains used in this study

\begin{tabular}{|c|c|c|}
\hline Strain & Relevant genotype or description & Source or reference \\
\hline 5-alpha & E. coli cloning host & New England BioLabs \\
\hline BL21(DE3) & E. coli protease-deficient expression host & Novagen \\
\hline GBS111 & Saccharomyces cerevisiae CEN.PK113-7D & \\
\hline NCBI3610 & Undomesticated wild-type $B$. subtilis isolate & \\
\hline OI3269 & Bacillus subtilis $168 \operatorname{trpC2}$ & \\
\hline Ol1085 & trpF7 hisH2 metC133 che ${ }^{+}$ & 97 \\
\hline PTS375 & $\Delta$ cheC $\Delta$ cheV & This work \\
\hline PTS097 & $\Delta c h e C$ & 25 \\
\hline PTS135 & $\Delta c h e V$ & 25 \\
\hline PTS185 & $\Delta m c p B$ & 25 \\
\hline PTS328 & $\triangle h e m A T$ & This work \\
\hline PTS238 & $\triangle m c p B \Delta$ hemAT & This work \\
\hline Ol3545 & $\Delta 10 m c p \mathrm{Erm}^{\mathrm{r}} \mathrm{Cm}^{\mathrm{r}} \mathrm{Kan}^{\mathrm{r}} \mathrm{che}^{+}$ & 24 \\
\hline Ol3921 & OI3545 amyE5720::mcpA Spc ${ }^{r}$ & 98 \\
\hline Ol3605 & OI3545 amyE5720::mcpB Spc ${ }^{r}$ & 5 \\
\hline Ol3974 & OI3545 amyE5720::mcpC Spc ${ }^{r}$ & 5 \\
\hline Ol4474 & OI3545 amyE5720::t/pA Spcr & 25 \\
\hline Ol4475 & OI3545 amyE5720::tlpB Spc ${ }^{r}$ & 25 \\
\hline Ol4483 & OI3545 amyE5720::tlpC Spc ${ }^{r}$ & 25 \\
\hline Ol4476 & Ol3545 amyE5720::yfmS Spcr & 25 \\
\hline Ol4477 & OI3545 amyE5720::yvaQ Spcr & 25 \\
\hline Ol4482 & OI3545 amyE5720::hemAT Spc ${ }^{r}$ & 25 \\
\hline Ol4479 & OI3545 amyE5720::yoaH Spc ${ }^{r}$ & 25 \\
\hline PTS522 & Ol3545 amyE5720::mcpB[M1-V287] mcpA[L287-E661] & This work \\
\hline PTS529 & Ol3545 amyE5720::mcpB[M1-Q359] mсpA[D359-E661] & This work \\
\hline GBS103 & OI3545 amyE5720::mcpB[M1-A374] mcpA[S374-E661] & This work \\
\hline GBS104 & Ol3545 amyE5720::mcpB[M1-N397] mcpA[E397-E661] & This work \\
\hline GBS142 & OI3545 amyE5720:: mсpB[M1-Q423] mсрA[A423-E661] & This work \\
\hline GBS090 & OI3545 amyE5720::mcpB[M1-1433] mсpA[Q433-E661] & This work \\
\hline GBS091 & OI3545 amyE5720::mcpB[M1-1481] mcpA[Q433-E661] & This work \\
\hline PTS252 & OI3545 amyE5720::mcpA[M1-Q358] mсpB[D359-E662] & This work \\
\hline GBS149 & OI3545 amyE5720::mcpB[A431S] & This work \\
\hline GBS176 & OI3545 amyE5720::mcpB[T424A] & This work \\
\hline GBS175 & OI3545 amyE5720::mcpB[D427T] & This work \\
\hline GBS158 & OI3545 amyE5720::mcpB[E581Q] & This work \\
\hline GBS170 & OI3545 amyE5720::mcpB[K585E] & This work \\
\hline GBS192 & OI3545 amyE5720::mcpB[E399K] & This work \\
\hline
\end{tabular}

the CHOPCHOP online tool (69). The $5^{\prime}$-end-phosphorylated complementary oligonucleotides were then annealed and subcloned into Bsal restriction sites on the pJSpe plasmid using Golden Gate assembly (70). The resultant plasmid was then linearized at the Spel restriction site and joined to two PCR fragments ( $\sim 700$ to $800 \mathrm{bp}$ ) flanking the targeted gene using Gibson assembly (71). Prior to transformation into the $B$. subtilis strain, each of the pJSpe-derived deletion plasmids was linearized at the Xhol restriction site and subsequently self-ligated to create a long DNA concatemer. The concatemer was then transformed into the $B$. subtilis strain using the two-step Spizizen method (72). The transformation product of the $B$. subtilis strain and the deletion plasmid concatemer was incubated on an LB agar (LB medium and 1.5\% agar) plate supplemented with $5 \mu \mathrm{g} / \mathrm{ml}$ kanamycin and $0.2 \%$ mannose for about $24 \mathrm{~h}$ at $30^{\circ} \mathrm{C}$. Next, single colonies were isolated and streaked twice onto fresh drug-containing plates (described above) to ensure a clonal genotype. Positive colonies were verified using colony PCR, again streaked onto a plain LB agar plate, and incubated for an additional $24 \mathrm{~h}$ at $50^{\circ} \mathrm{C}$ to cure the deletion plasmid. Colonies with cured plasmids were unable to grow on an LB agar plate supplemented with $5 \mu \mathrm{g} / \mathrm{ml}$ kanamycin

To construct chemoreceptor chimeras, two opposing primers were designed to amplify DNA regions outward from the fusion points of the chimeric gene using PCR with the PAIN750mcpB integration plasmid as the DNA template. Next, a second pair of primers with short overlapping regions was used to PCR amplify the desired fragment of the mcpA gene from pAIN750mcpA. Following the purification of PCR DNA products by gel extraction, the DNA fragments were assembled using Gibson assembly and transformed into $E$. coli. Following isolation from $E$. coli and sequence verification, the concatemer of the resultant integration plasmid was prepared as described above and transformed into B. subtilis OI3545, which lacks all 10 chemoreceptors. The transformation product was then incubated on an LB agar plate supplemented with $100 \mu \mathrm{g} / \mathrm{ml}$ spectinomycin for $15 \mathrm{~h}$ at $37^{\circ} \mathrm{C}$. Single colonies were isolated and streaked onto a TBAB agar (TBAB and $1.5 \%$ agar) plate supplemented with $1 \%$ soluble starch. A single positive colony with the chemoreceptor expression cassette recombined to the amyE locus was verified using a Gram iodine solution ( $0.33 \%$ iodine, $0.66 \%$ potassium iodide, and $1 \%$ sodium bicarbonate). Correct colonies with a disrupted amyE gene were unable to form clear zones on a TBAB-starch plate.

Point mutations on the $m c p B$ chemoreceptor gene were introduced using the inverse PCR method. Briefly, two opposing primers containing the desired mutations were used to PCR amplify the 
TABLE 2 Plasmids used in this study

\begin{tabular}{|c|c|c|}
\hline Plasmid & Description & Source or reference \\
\hline pET28a $(+)$ & His-tagged cloning vector for protein purification; Kan ${ }^{r}$ & Novagen \\
\hline pJSpe & Modified pJOE8999 optimized for Gibson assembly of homology templates; Ampr Kan ${ }^{r}$ & 25 \\
\hline рРT037 & pJSpe::cheV (for cheV knockout) & 25 \\
\hline рРТ058 & pJSpe::mcpB (for $m c p B$ knockout) & 25 \\
\hline рРТ053 & pJSpe::hemAT (for hemAT knockout) & This work \\
\hline pAIN750 & B. subtilis empty vector for integration at amyE; Ampr $\mathrm{Spc}^{r}$ & 98 \\
\hline pPT200 & pAIN750::mcpB[M1-V287] mcpA[L287-E661] & This work \\
\hline pPT205 & pAIN750::mcpB[M1-Q359] mcpA[D359-E661] & This work \\
\hline pGB42 & pAIN750::mcpB[M1-A374] mcpA[S374-E661] & This work \\
\hline pGB43 & pAIN750::mcpB[M1-N397] mсpA[E397-E661] & This work \\
\hline pGB34 & pAIN750::mcpB[M1-I433] mсpA[Q433-E661] & This work \\
\hline pGB64 & pAIN750::mcpB[M1-Q423] mсpA[A423-E661] & This work \\
\hline pGB35 & pAIN750::mcpB[M1-L481] mсpA[R481-E661] & This work \\
\hline рРТ086 & pAIN750::mcpA[M1-Q358]-mcpB[D359-E662] & This work \\
\hline pGB65 & pAIN750::mcpB[A431S] & This work \\
\hline pGB83 & pAIN750::mcpB[T424A] & This work \\
\hline pGB82 & pAIN750::mcpB[D427T] & This work \\
\hline pGB67 & pAIN750::mcpB[E581Q] & This work \\
\hline pGB79 & pAIN750::mcpB[K585E] & This work \\
\hline pGB94 & pAIN750::mcpB[E399K] & This work \\
\hline рPT262 & $\mathrm{His}_{6}$-C-terminal McpB expression plasmid, pET28(a)::mcpB $B_{C}$ & This work \\
\hline pGB78 & $\mathrm{His}_{6}$-C-terminal $\mathrm{McpB}_{C}-\mathrm{A} 431 \mathrm{~S}$ expression plasmid, pET28(a)::mcpB $B_{C}[A 431 \mathrm{~S}]$ & This work \\
\hline pGB53 & $\mathrm{His}_{6}$-C-terminal McpA expression plasmid, pET28(a)::mcpA $A_{C}$ & This work \\
\hline pGEX-6p-2::cheA & GST-CheA overexpression plasmid & 22 \\
\hline pGEX-6p-2::cheW & GST-CheW overexpression plasmid & 22 \\
\hline pGEX-6p-2::cheD & GST-CheD overexpression plasmid & 22 \\
\hline pGB46 & $\mathrm{His}_{6}$-C-terminal HemAT expression plasmid, pET28(a)::hemATs & This work \\
\hline pSP03 & $\mathrm{His}_{6}-\mathrm{N}$-terminal HemAT expression plasmid, pET28(a)::hemAT & This work \\
\hline
\end{tabular}

pAIN750mcpB integration plasmid. Following the purification of PCR DNA by gel extraction, the $5^{\prime}$ end of the DNA fragment was phosphorylated with T4 polynucleotide kinase and then blunt-end ligated using T4 DNA ligase. The ligation product was heat inactivated and transformed into E. coli. Following isolation from $E$. coli and sequence verification, the concatemer of the resultant integration plasmid was prepared as described above and transformed into $B$. subtilis Ol3545 to integrate the mutant chemoreceptor expression cassette into the amyE locus.

Protein expression plasmids were constructed with the pET28(+) expression vector system using Gibson assembly. Briefly, DNA for the HemAT sensing domain (residues 1 to 178) was cloned in frame with a $\mathrm{C}$-terminal $\mathrm{His}_{6}$ tag between the $\mathrm{Ncol}$ and Hindlll restriction sites on $\mathrm{pET} 28 \mathrm{a}(+)$. Similarly, the DNAs for the wild-type $M c p B$, wild-type $M c p A$, and McpB-A431S cytoplasmic regions, including the HAMP domain (residues 305 to 662 for McpB and residues 304 to 661 for McpA), were cloned in frame with a C-terminal $\mathrm{His}_{6}$ tag at the Ncol restriction site on pET28a(+). The DNA for the HemAT signaling domain (residues 177 to 432) was cloned in frame with an N-terminal His ${ }_{6}$ tag at the Nhel restriction site on $\mathrm{pET} 28 \mathrm{a}(+)$. After isolation and sequence verification, all plasmids were transformed into the $E$. coli BL21(DE3) strain for protein expression and purification.

Protein expression and purification. The CheA, CheW, and CheD proteins used in the kinase assay were expressed from glutathione $S$-transferase (GST) fusion plasmids and purified from the $E$. coli BL21(DE3) strain as described previously $(22,32)$. GSTrap columns (5 ml; GE Healthcare) were used with an Äkta Prime fast protein liquid chromatography (FPLC) system (GE Healthcare) for purification. To purify the GST fusion proteins, cells were grown in 2 liters of LB broth with $100 \mu \mathrm{g} / \mathrm{ml}$ ampicillin at $37^{\circ} \mathrm{C}$ with shaking at $250 \mathrm{rpm}$ until the optical density at $600 \mathrm{~nm}\left(\mathrm{OD}_{600}\right)$ reached 0.8 . Expression was then induced by the addition of $1 \mathrm{mM}$ IPTG (isopropyl- $\beta$-D-thiogalactopyranoside), and the culture was grown for 12 $\mathrm{h}$ at $25^{\circ} \mathrm{C}$ with shaking at $250 \mathrm{rpm}$. For CheA, the culture was induced at $37^{\circ} \mathrm{C}$ for $4 \mathrm{~h}$. Cells were then centrifuged at $8,000 \times g$ for $8 \mathrm{~min}$ and resuspended in Tris-buffered saline (TBS) (50 mM Tris, $150 \mathrm{mM}$ $\mathrm{NaCl}$ [pH 7.5]) supplemented with $1 \%$ Triton X-100 and $1 \mathrm{mM}$ dithiothreitol (DTT) for every $1 \mathrm{~g}$ of cell pellet. The cells were then disrupted by sonication (5 10-s pulses). The supernatants were clarified by two rounds of centrifugation $(9,000 \times g$ for $15 \mathrm{~min}$ and $40,000 \times g$ for $40 \mathrm{~min})$ and loaded onto 5 -ml GSTrap columns prewashed with 10 column volumes of TBS. Protein-bound columns were then washed with at least 15 volumes of TBS, and GST-tagged proteins were eluted using $10 \mathrm{ml}$ glutathione elution buffer (GEB) (50 mM Tris, $5 \mathrm{mM}$ glutathione [pH 8]). To remove the GST tag, the purified proteins were cleaved by PreScission protease, as specified by the supplier (Amersham Biosciences), and applied to another 5-ml GSTrap column. The flowthrough was collected and concentrated to approximately $5 \mathrm{ml}$ using a cellulose ultrafiltration membrane (Millipore) in an Amicon ultrafiltration cell. Finally, the purified proteins were dialyzed in TKMD buffer (50 mM Tris, $50 \mathrm{mM} \mathrm{KCl}, 5 \mathrm{mM} \mathrm{MgCl} 2,0.1 \mathrm{mM} \mathrm{DTT}$ [pH 8]), and aliquots were stored at $-80^{\circ} \mathrm{C}$.

E. coli $\mathrm{BL} 21(\mathrm{DE} 3)$ cells harboring the $\mathrm{His}_{6}$-tagged expression plasmids were grown in 2 liters of LB medium supplemented with $30 \mu \mathrm{g} / \mathrm{ml}$ kanamycin at $37^{\circ} \mathrm{C}$ with shaking at $250 \mathrm{rpm}$ until the $A_{600}$ reached 
0.7. Expression was then induced by the addition of $1 \mathrm{mM}$ IPTG, and the cultures were grown for $12 \mathrm{~h}$ at $25^{\circ} \mathrm{C}$. Cells were harvested by centrifugation at $7,000 \times g$ at $4{ }^{\circ} \mathrm{C}$ for $10 \mathrm{~min}$. Cells harboring $\mathrm{HemAT}_{\mathrm{N}}$ were resuspended in lysis buffer $\left(50 \mathrm{mM} \mathrm{NaH}_{2} \mathrm{PO}_{4}, 300 \mathrm{mM} \mathrm{NaCl}, 10 \mathrm{mM}\right.$ imidazole [pH 8]) and sonicated (5 10-s pulses). Cell debris was removed by centrifugation at $12,000 \times g$ for $1 \mathrm{~h}$. The dark-red supernatant containing HemAT $\mathrm{N}_{\mathrm{N}}$ was loaded onto a $5-\mathrm{ml}$ GE HisTrap column prewashed with $\mathrm{NiSO}_{4}$ and binding buffer $\left(50 \mathrm{mM} \mathrm{NaH}_{2} \mathrm{PO}_{4}, 300 \mathrm{mM} \mathrm{NaCl}, 20 \mathrm{mM}\right.$ imidazole [pH 8]). The protein-bound column was then washed with binding buffer, and proteins were eluted with elution buffer $\left(50 \mathrm{mM} \mathrm{NaH}_{2} \mathrm{PO}_{4}, 300 \mathrm{mM}\right.$ $\mathrm{NaCl}, 250 \mathrm{mM}$ imidazole $[\mathrm{pH} 8])$. The collected $\mathrm{HemAT}_{\mathrm{N}}$ protein samples were concentrated using an Amicon ultrafiltration cell (Millipore) and dialyzed into dialysis buffer (50 mM Tris, $300 \mathrm{mM} \mathrm{NaCl}[\mathrm{pH} 8]$ ) at $4^{\circ} \mathrm{C}$, and aliquots were stored at $-80^{\circ} \mathrm{C}$.

The $\mathrm{McpB}_{\mathrm{C}}, \mathrm{McpB}_{\mathrm{C}}-\mathrm{A} 431 \mathrm{~S}, \mathrm{McpA}_{\mathrm{C}}$, and HemAT proteins were purified under denaturing conditions. Briefly, cells were induced and grown as described above. Cells were then resuspended in buffer B (8 M urea, $0.1 \mathrm{M} \mathrm{NaH}_{2} \mathrm{PO}_{4}, 0.01 \mathrm{M}$ Tris [pH 8]) with $1 \%$ Triton X-100 and $1 \mathrm{mM} \mathrm{DTT}$ for every $1 \mathrm{~g}$ of cell pellet and incubated at room temperature for $1 \mathrm{~h}$. The cell suspension was clarified by centrifugation at $40,000 \times g$ for $1 \mathrm{~h}$. The cell lysates were loaded onto a 5-ml GE Hi-Trap chelating column charged with $0.1 \mathrm{M} \mathrm{NiSO}_{4}$ and washed with buffer $\mathrm{B}$ and buffer $\mathrm{C}$ (buffer $\mathrm{B}$ at $\mathrm{pH}$ 6.3). The fusion proteins were eluted from the column with $25 \mathrm{ml}$ elution buffer $\mathrm{E}$ (buffer $\mathrm{B}$ at $\mathrm{pH}$ 4.5). Proteins were refolded by dialysis in phosphate-buffered saline (PBS) $\left(10 \mathrm{mM} \mathrm{Na}_{2} \mathrm{HPO}_{4}, 1.8 \mathrm{mM} \mathrm{KH}_{2} \mathrm{PO}_{4}, 137 \mathrm{mM} \mathrm{NaCl}, 2.7 \mathrm{mM} \mathrm{KCl}\right.$ [pH 7.4]) at $4^{\circ} \mathrm{C}$, and aliquots were stored at $-80^{\circ} \mathrm{C}$. The proper folding of purified proteins was verified by circular dichroism (CD) spectroscopy. The concentrations of all purified proteins were quantified by a Pierce bicinchoninic acid (BCA) protein assay kit. SDS-PAGE images of the purified recombinant chemoreceptor proteins are provided in Data Set S1.

Capillary assay for chemotaxis. The capillary assay was performed as described previously (73). Briefly, cells were grown for $16 \mathrm{~h}$ at $30^{\circ} \mathrm{C}$ on TBAB plates. The cells were then scraped from the plates and resuspended to an $\mathrm{OD}_{600}$ of 0.03 in $5 \mathrm{ml}$ CAMM supplemented with $50 \mu \mathrm{g} / \mathrm{ml}$ histidine, $50 \mu \mathrm{g} / \mathrm{ml}$ methionine, $50 \mu \mathrm{g} / \mathrm{ml}$ tryptophan, $20 \mathrm{mM}$ sorbitol, and 2\% TB. The cultures were grown to an $\mathrm{OD}_{600}$ of 0.4 to 0.45 at $37^{\circ} \mathrm{C}$ with shaking at $250 \mathrm{rpm}$. At this point, $50 \mu \mathrm{l}$ of GL solution (5\% [vol/vol] glycerol and $0.5 \mathrm{M}$ sodium lactate) was added, and cells were incubated for another $15 \mathrm{~min}$ (at $37^{\circ} \mathrm{C}$ with shaking at $250 \mathrm{rpm})$. The cells were then washed twice with chemotaxis buffer and incubated for an additional $25 \mathrm{~min}$ (at $37^{\circ} \mathrm{C}$ with shaking at $250 \mathrm{rpm}$ ) to ensure that the cells were motile. The cells were then diluted to an $\mathrm{OD}_{600}$ of 0.001 in chemotaxis buffer and aliquoted into $0.3-\mathrm{ml}$ ponds on a slide warmer at $37^{\circ} \mathrm{C}$, and closed-end capillary tubes filled with alcohol solutions or an asparagine solution (3.16 $\mu \mathrm{M})$ prepared in the same chemotaxis buffer were inserted. After $30 \mathrm{~min}$, cells in the capillaries were harvested, transferred to $3 \mathrm{ml}$ of top agar ( $1 \%$ tryptone, $0.8 \% \mathrm{NaCl}, 0.8 \%$ agar, and $0.5 \mathrm{mM}$ EDTA), and plated onto TB agar (TB and $1.5 \%$ agar) plates. These plates were incubated for $16 \mathrm{~h}$ at $37^{\circ} \mathrm{C}$, and colonies were counted. Experiments were performed in triplicate each day and repeated on three different days.

Cell growth. Cell density was measured as the optical absorbance at $600 \mathrm{~nm}$. Briefly, B. subtilis 168 was first grown for $16 \mathrm{~h}$ at $30^{\circ} \mathrm{C}$ on a TBAB plate. For growth experiments in minimal medium, the cells were first scraped from the TBAB plate and then resuspended to an $\mathrm{OD}_{600}$ of 0.03 in $50 \mathrm{ml}$ CAMM supplemented with $50 \mu \mathrm{g} / \mathrm{ml}$ tryptophan and $5 \mathrm{~g} /$ liter glucose and grown at $37^{\circ} \mathrm{C}$ with shaking at $250 \mathrm{rpm}$. At an $\mathrm{OD}_{600}$ of 0.8 , the cells were diluted 1:20 (vol/vol) into $50 \mathrm{ml} \mathrm{CAMM} \mathrm{containing} 50 \mu \mathrm{g} / \mathrm{ml}$ tryptophan supplemented with $0.01 \mathrm{M}$ ethanol, $0.1 \mathrm{M}$ ethanol, or $5 \mathrm{~g} /$ liter glucose (positive control) and grown for $24 \mathrm{~h}$ at $37^{\circ} \mathrm{C}$ with shaking at $250 \mathrm{rpm}$. For growth experiments in rich medium, cell cultures starting at an $\mathrm{OD}_{600}$ of 0.03 were grown to an $\mathrm{OD}_{600}$ of 0.4 at $37^{\circ} \mathrm{C}$ with shaking at $250 \mathrm{rpm}$ in $50 \mathrm{ml} \mathrm{LB}$ medium. At this point, cell cultures were supplemented with $0.01 \mathrm{M}, 0.1 \mathrm{M}$, or $1.0 \mathrm{M}$ ethanol and grown for another $5 \mathrm{~h}$ at $37^{\circ} \mathrm{C}$ with shaking at $250 \mathrm{rpm}$. All growth experiments were performed in triplicate.

Ethanol utilization experiments. Ethanol concentrations were measured using a Shimadzu highperformance liquid chromatography system equipped with a RID-10A refractive index detector, an Aminex HPX-87H carbohydrate analysis column (Bio-Rad Laboratories), and a cation $\mathrm{H}$ micro-guard cartridge (Bio-Rad Laboratories). The column and guard cartridge were kept at $65^{\circ} \mathrm{C}$, and $0.5 \mathrm{mM} \mathrm{H}_{2} \mathrm{SO}_{4}$ was used a mobile phase at a constant flow rate of $0.6 \mathrm{ml} / \mathrm{min}$. Prior to measurements, cells in culture samples were pelleted, and the resulting supernatant was passed through a $0.22-\mu \mathrm{m}$ polyethersulfone syringe filter. Peaks were identified and quantified by retention time comparison to the standards.

Alcohol dehydrogenase activity measurement. B. subtilis 011085 was first grown for $16 \mathrm{~h}$ at $30^{\circ} \mathrm{C}$ on a TBAB plate. For aerobic growth, the cells were then scraped from the TBAB plate; resuspended to an $\mathrm{OD}_{600}$ of 0.03 in $5 \mathrm{ml}$ CAMM supplemented with $50 \mu \mathrm{g} / \mathrm{ml}$ histidine, $50 \mu \mathrm{g} / \mathrm{ml}$ methionine, $50 \mu \mathrm{g} / \mathrm{ml}$ tryptophan, $20 \mathrm{mM}$ sorbitol, and $2 \% \mathrm{~TB}$; and grown at $37^{\circ} \mathrm{C}$ with vigorous shaking at $250 \mathrm{rpm}$. For anaerobic growth, however, cells were cultured starting at an $\mathrm{OD}_{600}$ of 0.03 in a sealed bottle filled to the top without agitation in CAMM supplemented with $1 \%$ glucose and a mixture of all 20 amino acids at $50 \mu \mathrm{g} / \mathrm{ml}$ (29). For E. coli cultures, the cells (MG1655) were grown in M9 medium supplemented with $0.4 \%$ glucose at $37^{\circ} \mathrm{C}$ in sealed bottles filled to the top without agitation for anaerobic growth and in flasks with shaking at $250 \mathrm{rpm}$ for aerobic growth (31). All cell cultures were grown to stationary phase prior to sonication (7 10-s pulses), and soluble cell extracts were obtained by centrifugation $\left(7,000 \times g\right.$ at $4^{\circ} \mathrm{C}$ for $10 \mathrm{~min}$ ). Alcohol dehydrogenase enzyme assays were performed as described previously (74). Briefly, the assay reaction mixtures were prepared with $22 \mathrm{mM}$ sodium pyrophosphate $(\mathrm{pH} 8.8), 0.3 \mathrm{mM}$ sodium phosphate, $7.5 \mathrm{mM} \beta-\mathrm{NAD}, 0.003 \%$ (wt/vol) bovine serum albumin, $1.6 \%$ ( $\mathrm{vol} / \mathrm{vol}$ ) of the desired cell lysate, and $3.2 \%$ ( $\mathrm{vol} / \mathrm{vol}$ ) ethanol in a $200-\mu \mathrm{l}$ reaction volume. Next, the reduction of NAD ${ }^{+}$to NADH was recorded at $340 \mathrm{~nm}$ using a Shimadzu UV-1800 spectrophotometer. One unit of alcohol dehydrogenase activity is defined as the amount of enzyme that converts $1 \mu \mathrm{mol}$ of ethanol to acetaldehyde per min at $\mathrm{pH} 8.8$ at $25^{\circ} \mathrm{C}$. 
Antimicrobial diffusion assay. The antifungal activities of the $B$. subtilis strains were assayed using the disc diffusion method as described previously (75). Briefly, S. cerevisiae CEN.PK113-7D was grown in YPD rich medium for $24 \mathrm{~h}$ at $30^{\circ} \mathrm{C}$ with shaking at $200 \mathrm{rpm}$. A total of $0.1 \%$ (vol/vol) of the yeast culture was mixed with YPD top agar (YPD medium with $0.8 \%$ agar) and spread on top of a YPD plate (YPD medium with $2 \%$ agar). Once the top yeast layer was solidified, 10-mm filter paper (Whatman filter paper, grade 1) discs loaded with supernatants from $B$. subtilis strains grown overnight in LB medium at $37^{\circ} \mathrm{C}$ were placed on top of the yeast layer. As negative controls, separate discs were loaded with LB broth and water. The plate was incubated at $30^{\circ} \mathrm{C}$ for another $24 \mathrm{~h}$ and then imaged. A zone of inhibition around the discs indicated antifungal activity.

Preparation of bacterial membranes. Cells were grown for $16 \mathrm{~h}$ at $30^{\circ} \mathrm{C}$ on TBAB plates. The cells were then scraped from the plates and resuspended to an $\mathrm{OD}_{600}$ of 0.03 in $50 \mathrm{ml}$ CAMM supplemented with $50 \mu \mathrm{g} / \mathrm{ml}$ histidine, $50 \mu \mathrm{g} / \mathrm{ml}$ methionine, $50 \mu \mathrm{g} / \mathrm{ml}$ tryptophan, $20 \mathrm{mM}$ sorbitol, and $2 \%$ TB. The cells were grown at $37^{\circ} \mathrm{C}$ with aeration until they reached mid-exponential phase. The cells were then diluted 1:10 ( $\mathrm{vol} / \mathrm{vol})$ into $50 \mathrm{ml} \mathrm{CAMM}$ and grown until mid-exponential phase. The cells were again diluted to an $\mathrm{OD}_{600}$ of 0.01 in $50 \mathrm{ml}$ medium and grown until mid-exponential phase. Finally, the cultures were diluted 1:10 ( $\mathrm{vol} / \mathrm{vol})$ into multiple flasks containing $50 \mathrm{ml}$ medium and grown with shaking at $37^{\circ} \mathrm{C}$ until an $\mathrm{OD}_{600}$ of 0.6 was reached. The cells were then harvested by centrifugation at $9,900 \times g$ for $15 \mathrm{~min}$ and washed 3 times with $1 \mathrm{M} \mathrm{KCl}$ to remove extracellular proteases. Cells were resuspended in sonication buffer plus ( $10 \mathrm{mM}$ potassium phosphate [pH 7], $10 \mathrm{mM} \mathrm{MgCl}, 1 \mathrm{mM}$ EDTA, $0.3 \mathrm{mM}$ DT, $20 \mathrm{mM} \mathrm{KCl}$, $1 \mathrm{mM}$ glutamate, $2 \mathrm{mM}$ phenylmethanesulfonyl fluoride, and 20\% glycerol). EDTA and phenylmethanesulfonyl fluoride were added as protease inhibitors. Cells were sonicated, and the cell debris was removed by centrifugation at $17,600 \times g$ at $4^{\circ} \mathrm{C}$ for $15 \mathrm{~min}$. Bacterial membranes were removed by centrifugation at $120,000 \times g$ for $2 \mathrm{~h}$ at $4^{\circ} \mathrm{C}$ in a Beckman $70 \mathrm{Ti}$ rotor. Pelleted membranes were resuspended in MT buffer (10 $\mathrm{mM}$ potassium phosphate $[\mathrm{pH} 7], 1 \mathrm{mM} \mathrm{MgCl}{ }_{2}, 0.1 \mathrm{mM}$ EDTA, and $1 \mathrm{mM}$ 2-mercaptoethanol) and homogenized using a glass-Teflon homogenizer, followed by another centrifugation step at $120,000 \times g$ for $2 \mathrm{~h}$ at $4^{\circ} \mathrm{C}$. This step was repeated once more. Finally, the membranes were homogenized in MT buffer at a concentration of $32 \mathrm{mg} / \mathrm{ml}$ and stored in small aliquots at $-80^{\circ} \mathrm{C}$.

In vitro assay for receptor-coupled kinase activity. Reaction mixtures consisted of purified $B$. subtilis membranes expressing McpB or HemAT as the sole chemoreceptor and purified CheW, CheA, and CheD prepared in buffer ( $50 \mathrm{mM}$ Tris, $50 \mathrm{mM} \mathrm{KCl}, 5 \mathrm{mM} \mathrm{MgCl}$ [ $[\mathrm{pH} 7.5]$ ) at the following concentrations: $6 \mu \mathrm{M}$ chemoreceptor, $2 \mu \mathrm{M}$ CheW, $2 \mu \mathrm{M}$ CheA kinase, and $2 \mu \mathrm{M}$ CheD. Ethanol was then added to the mixture at different final concentrations in a $20-\mu \mathrm{l}$ reaction volume. As a negative control, only buffer was added. Reaction mixtures were then preincubated at $23^{\circ} \mathrm{C}$ for $1 \mathrm{~h}$ to permit the formation of the chemoreceptor-kinase complex. CheA autophosphorylation was initiated by the addition of [ $\gamma^{3}{ }^{32}$ P]ATP $(4,000$ to $8,000 \mathrm{cpm} / \mathrm{pmol})$ to a final concentration of $0.1 \mathrm{mM}$. Five-microliter aliquots were quenched at $15 \mathrm{~s}$ by mixing the reaction mixtures with $15 \mu \mathrm{l}$ of $2 \times$ Laemmli sample buffer containing $25 \mathrm{mM}$ EDTA at room temperature, essentially fixing the level of phosphor-CheA. Initial phosphor-CheA formation rates were analyzed using 12\% SDS-PAGE gels. Gels were dried immediately after electrophoresis, and phosphor-CheA was quantified by phosphorimaging (Molecular Dynamics) and ImageJ (76).

Circular dichroism spectroscopy. Far-UV CD spectra were measured on a Jasco J-720 spectropolarimeter (Japan Spectroscopic Co., Inc., Tokyo, Japan) with a cuvette with a path length of $0.1 \mathrm{~cm}$. Prior to measurements, protein samples were dialyzed into $10 \mathrm{mM}$ sodium phosphate buffer $(\mathrm{pH}$ 8) and diluted to $2.5 \mu \mathrm{M}$. Spectral measurements were carried out in triplicate using a scanning rate of $50 \mathrm{~nm} / \mathrm{min}$ and a $0.1-\mathrm{nm}$ step size with 5 accumulations per sample. A buffer-only control sample was used for baseline correction, and curves were smoothed according to the Savitzky-Golay algorithm (77). Structural analysis was done using BeStSel (78).

UV-visible spectral measurements. All UV spectral measurements were performed on a Shimadzu UV-1800 spectrophotometer. The UV spectra of the oxygenated sensing domain of the HemAT $\left(\mathrm{HemAT}_{N}\right)$ protein were measured under aerobic conditions. To measure the UV spectra of $\mathrm{HemAT}_{N}$ in the presence of ethanol, protein samples were first deoxygenated by adding a few grains of sodium dithionite in a glove box. Sodium dithionite-reduced protein samples were then titrated with different doses of ethanol in sealed quartz cuvettes, and the UV spectra $(200 \mathrm{~nm}$ to $600 \mathrm{~nm})$ of these samples were immediately recorded in the spectrophotometer.

Saturation transfer difference nuclear magnetic resonance spectroscopy. All nuclear magnetic resonance (NMR) spectroscopy measurements were performed on a Varian VNMRS instrument at $750 \mathrm{MHz}$ with a $5-\mathrm{mm}$ Varian $\mathrm{HCN}$ probe at $298 \mathrm{~K}$ without sample spinning. Prior to measurements, protein samples were buffer exchanged into PBS (50 mM KH $\left.\mathrm{PO}_{4}, 20 \mathrm{mM} \mathrm{NaCl}[\mathrm{pH} 7.4]\right)$ in $\mathrm{D}_{2} \mathrm{O}$ using Micro Bio-Spin columns with Bio-Gel P-6 (Bio-Rad Laboratories, Hercules, CA, USA). To avoid aggregation, $\mathrm{HemAT}_{\mathrm{N}}$ protein was buffer exchanged into modified PBS $\left(50 \mathrm{mM} \mathrm{K \textrm {KH } _ { 2 }} \mathrm{PO}_{4}, 300 \mathrm{mM} \mathrm{NaCl}\right.$ [pH 8.0]) containing $10 \% \mathrm{D}_{2} \mathrm{O}$. Protein samples at $50 \mu \mathrm{M}$ were then mixed with the alcohol (final concentration of $3 \mathrm{mM}$ ) in a $500-\mu$ l solution. ${ }^{1} \mathrm{H}$ spectra were obtained from 32 scans with a $90^{\circ}$ pulse and a 2 -s relaxation delay. In saturation transfer difference NMR (STD-NMR) experiments, the protein samples were selectively saturated at $2.15 \mathrm{ppm}$ with a train of Gaussian pulses of a 50-ms duration with a $0.1-\mathrm{ms}$ delay and a 5 -s relaxation delay for a total saturation time of $3 \mathrm{~s}$ and 2,048 scans. Off-resonance irradiation was applied at $30 \mathrm{ppm}$. A trim pulse of $50 \mathrm{~ms}$ was used to reduce protein background. In the case of $\mathrm{HemAT}_{N^{\prime}}$ the protein sample was saturated at $7.06 \mathrm{ppm}$, and 256 scans were used to obtain spectra. All STD spectra were obtained by internal subtraction via phase cycling after a block size of 8 to reduce artifacts resulting from temperature variation and magnet instability. Control experiments were performed on samples containing only the alcohol without protein. All areas were calculated using MNova V14.1 (by Mestrelab Chemistry Solutions) in stacked mode. 
Structural analysis. Domains of the McpB, McpA, TIpA, and TIpB chemoreceptors from B. subtilis were predicted using the phmmer search engine on the HMMER Web server using the UniProt reference proteome database with default sequence $E$ value thresholds (79). The amino acid sequences of the cytoplasmic signaling domains were then manually obtained based on previous large-scale alignment results (10). To identify the three structural subdomains of the cytoplasmic signaling domain, the sequences were then aligned with the amino acid sequences of the corresponding domains from the Tar, Tsr, Trg, and Tap chemoreceptors of E. coli using MUSCLE (80) with default parameter values. Pairwise amino acid sequence alignments between the protein pairs (McpA-McpB, McpA-HemAT, and HemAT$\mathrm{YfmS}$ ) for chimeric receptor analysis were performed using EMBOSS Water (81). A homology model of the cytoplasmic signaling domain of the McpB dimer (residues 352 to 662) was constructed in Modeller ( $v$-9.23) (82) using the Thermotoga maritima Tm113 chemoreceptor (PDB accession number 2CH7) as the template (83). Side chain conformations were refined using SCWRL4 (84), and the entire structural model was subsequently refined using the YASARA energy minimization server (85). The resulting Ramachandran plots were verified using Procheck (86). The crystal structure of the HemAT sensing domain from $B$. subtilis (PDB accession number 1OR6) (40) was used for visualization. Visualization of all structures was accomplished using the VMD software package (v-1.9.3) (87).

Receptor-ligand in silico docking experiment. The putative binding sites for ethanol were determined using Autodock (v-4.0) (88). Briefly, hydrogen atoms were first added to the McpB cytoplasmic signaling domain dimer model, and the number of torsional degrees of freedom for ethanol was set at 1. Autogrid was then used to adjust the position of grid boxes ( 60 by 60 by 60 points with $0.375-\AA$ spacing for each box) on the ethanol-sensing region (residues 390 to 435). Finally, the Lamarckian genetic algorithm was employed to obtain the best docking site configurations.

Molecular dynamics simulations. All-atom molecular dynamics simulations were conducted using NAMD 2.13 (89) and the CHARMM36 force field (90). Simulations were carried out using the NPT ensemble (pressure of $1 \mathrm{~atm}$ and temperature of $310 \mathrm{~K}$ ) with values for general simulation parameters as previously described (91). The McpB cytoplasmic dimer model was solvated with TIP3P (transferable intermolecular potential with 3 points) water and $150 \mathrm{mM} \mathrm{NaCl}$ using VMD (87), and 165 ethanol molecules $(0.316 \mathrm{M})$ were randomly placed within the simulation box using the gmx insert-molecules tool. A copy of the system that included the A431S mutation was created, and both the wild-type and mutant McpB-ethanol systems were subjected to conjugant gradient energy minimization (2,000 steps), followed by a 10 -ns equilibration simulation with protein backbone restraints and 3600 -ns unrestrained production simulations.

Molecular dynamics simulation analysis. Density maps representing the average ethanol occupancy were computed using the VolMap plug-in in VMD with default settings and averaging over each production simulation for the wild-type and A431S mutant McpB-ethanol systems. To highlight unique binding sites between the two maps, a difference map was computed by subtracting the A431S map from the wild-type map using VMD's volutil plug-in and removing smaller volumes resulting from slight irregularities in overlapping sites using the "hide dust" feature in UCSF Chimera. All densities are visualized at an isovalue of 0.03 except for the difference map, which used an isovalue of 0.015 . Protein-ethanol coordination was computed by measuring the minimum distance between nonhydrogen atoms in each residue and the nearest ethanol molecule; if this distance was less than $4 \AA$, the pair was considered to be in contact. Average coordination values were computed for each residue in the wild-type and A431S mutant McpB-ethanol systems by averaging over all three production simulations at 200-ps intervals. Percent changes were obtained by subtracting the values obtained in the latter from those obtained in the former. Knobs-in-holes packing within the McpB cytoplasmic signaling domain was analyzed using the program SOCKET (92) with a packing cutoff of $7.8 \AA$ (93). For each production simulation, knobs-in-holes packing was assessed at 2-ns intervals over the course of the trajectory, not including the first $100 \mathrm{~ns}$ to allow for packing changes resulting from equilibration or the A431S mutation. The occupancy of a particular knob-in-hole interaction over a given simulation was taken as the number of intervals in which it was identified by SOCKET divided by the total number of intervals analyzed in the simulation. The reported knobs-in-holes occupancies were averaged over both McpB monomers and all three production simulations for each McpB-ethanol system; error bars denote 1 standard deviation from the mean.

Simulation of ethanol diffusion in the capillary assay. The spatiotemporal evolution of ethanol $(C)$ in the capillary assay was modeled using Fick's second-law equation with Neumann (no-flux) boundary conditions shown in the following equation: $\partial C / \partial t=D \Delta C$. The initial ethanol concentrations were set to $50 \mathrm{mM}$ in the capillary and $0 \mathrm{mM}$ in the pond. The ethanol diffusion coefficient $(D)$ was assumed to be $1.23 \times 10^{-3} \mathrm{~mm}^{2} / \mathrm{s}$ (94). The above-described partial differential equation was solved using the finite-element method with the help of FEniCS (v-2019.1.0), an open-source computing platform (95). Briefly, the computation domain consists of the capillary and the proximal region near the mouth of the capillary in the pond. The capillary was modeled as a $10-\mathrm{mm}$-long cylinder with a diameter of $0.2 \mathrm{~mm}$ attached to an 8-mm-long cylinder with a diameter of $4 \mathrm{~mm}$. Gmsh (v-4.5.2) (96) was used to generate the three-dimensional finite-element mesh, and the XML file of the resulting mesh was produced using the meshio-convert tool available from FEniCS. The implicit Euler method was employed for time integration with a step size of $\Delta t=1 \mathrm{~s}$. A custom Python script was generated for solving the finite-element problem.

Data availability. Raw data for all experiments except STD-NMR are provided in Data Set S1 in the supplemental material. Raw data for the STD-NMR experiments are available upon request. The Python script for diffusion simulation is provided at https://github.com/paymantohidifar/alcoholtaxis. 
SUPPLEMENTAL MATERIAL

Supplemental material is available online only.

FIG S1, TIF file, $1 \mathrm{MB}$

FIG S2, TIF file, $2.9 \mathrm{MB}$.

FIG S3, TIF file, $2 \mathrm{MB}$.

FIG S4, TIF file, $0.5 \mathrm{MB}$.

FIG S5, TIF file, 2.4 MB.

FIG S6, TIF file, 1.3 MB.

FIG S7, TIF file, $0.6 \mathrm{MB}$.

TABLE S1, PDF file, $0.02 \mathrm{MB}$.

TABLE S2, PDF file, 0.1 MB.

DATA SET S1, XLSX file, $0.3 \mathrm{MB}$.

\section{ACKNOWLEDGMENTS}

We thank Jodi A. Hadden-Perilla for discussions surrounding the use of SOCKET. We also thank Lingyang Zhu, Dean Olson, and the SCS NMR laboratory at the University of Illinois at Urbana-Champaign for valuable inputs and help with NMR measurements and Ahmed Hetta and Isaac Cann for help with CD spectroscopy experiments.

This work was partially funded by National Institutes of Health grant GM054365 and by the University of Illinois through the Robert W. Schaefer Faculty Scholar Fund.

\section{REFERENCES}

1. Adler J. 1966. Chemotaxis in bacteria. Science 153:708-716. https://doi .org/10.1126/science.153.3737.708.

2. Ortega A, Zhulin IB, Krell T. 2017. Sensory repertoire of bacterial chemoreceptors. Microbiol Mol Biol Rev 81:e00033-17. https://doi.org/10.1128/ MMBR.00033-17.

3. Rao CV, Ordal GW. 2009. The molecular basis of excitation and adaptation during chemotactic sensory transduction in bacteria. Contrib $\mathrm{Mi}$ crobiol 16:33-64. https://doi.org/10.1159/000219372.

4. Rao CV, Glekas GD, Ordal GW. 2008. The three adaptation systems of Bacillus subtilis chemotaxis. Trends Microbiol 16:480-487. https://do .org/10.1016/j.tim.2008.07.003.

5. Kristich CJ, Glekas GD, Ordal GW. 2003. The conserved cytoplasmic module of the transmembrane chemoreceptor McpC mediates carbohydrate chemotaxis in Bacillus subtilis. Mol Microbiol 47:1353-1366. https://doi.org/10.1046/j.1365-2958.2003.03375.x.

6. Neumann S, Grosse K, Sourjik V. 2012. Chemotactic signaling via carbohydrate phosphotransferase systems in Escherichia coli. Proc Natl Acad Sci U S A 109:12159-12164. https://doi.org/10.1073/pnas.1205307109.

7. Umemura T, Matsumoto Y, Ohnishi K, Homma M, Kawagishi I. 2002. Sensing of cytoplasmic $\mathrm{pH}$ by bacterial chemoreceptors involves the linker region that connects the membrane-spanning and the signalmodulating helices. J Biol Chem 277:1593-1598. https://doi.org/10.1074/ jbc.M109930200.

8. Bi S, Jin F, Sourjik V. 2018. Inverted signaling by bacterial chemotaxis receptors. Nat Commun 9:2927. https://doi.org/10.1038/s41467-018 $-05335-w$.

9. Vaknin A, Berg HC. 2006. Osmotic stress mechanically perturbs chemoreceptors in Escherichia coli. Proc Natl Acad Sci U S A 103:592-596. https://doi.org/10.1073/pnas.0510047103.

10. Alexander RP, Zhulin IB. 2007. Evolutionary genomics reveals conserved structural determinants of signaling and adaptation in microbial chemoreceptors. Proc Natl Acad Sci U S A 104:2885-2890. https://doi.org/10.1073/ pnas.0609359104.

11. Dombek KM, Ingram LO. 1986. Determination of the intracellular concentration of ethanol in Saccharomyces cerevisiae during fermentation. Appl Environ Microbiol 51:197-200. https://doi.org/10.1128/AEM.51.1 .197-200.1986.

12. Osman YA, Ingram LO. 1985. Mechanism of ethanol inhibition of fermentation in Zymomonas mobilis CP4. J Bacteriol 164:173-180. https:// doi.org/10.1128/JB.164.1.173-180.1985.

13. Schoberth SM, Chapman BE, Kuchel PW, Wittig RM, Grotendorst J, Jansen P, DeGraff AA. 1996. Ethanol transport in Zymomonas mobilis measured by using in vivo nuclear magnetic resonance spin transfer. J Bacteriol 178: 1756-1761. https://doi.org/10.1128/jb.178.6.1756-1761.1996.
14. Stein WD. 1986. Transport and diffusion across cell membranes. Academic Press, Inc, San Diego, CA. https://doi.org/10.1016/b978-0-12-664660-3 .X5001-7.

15. Stock JB, Rauch B, Roseman S. 1977. Periplasmic space in Salmonella typhimurium and Escherichia coli. J Biol Chem 252:7850-7861.

16. Yang NJ, Hinner MJ. 2015. Getting across the cell membrane: an overview for small molecules, peptides, and proteins. Methods Mol Biol 1266:29-53. https://doi.org/10.1007/978-1-4939-2272-7_3.

17. Stewart GG, Panchal CJ, Russell I, Sills AM. 1983. Biology of ethanolproducing microorganisms. Crit Rev Biotechnol 1:161-188. https://doi .org/10.3109/07388558309077977.

18. Glekas GD, Foster RM, Cates JR, Estrella JA, Wawrzyniak MJ, Rao CV, Ordal GW. 2010. A PAS domain binds asparagine in the chemotaxis receptor McpB in Bacillus subtilis. J Biol Chem 285:1870-1878. https://doi.org/10 .1074/jbc.M109.072108.

19. Glekas GD, Mulhern BJ, Kroc A, Duelfer KA, Lei V, Rao CV, Ordal GW. 2012. The Bacillus subtilis chemoreceptor McpC senses multiple ligands using two discrete mechanisms. J Biol Chem 287:39412-39418. https://doi .org/10.1074/jbc.M112.413518.

20. Ordal GW, Villani DP, Gibson KJ. 1977. Amino acid chemoreceptors of Bacillus subtilis. J Bacteriol 129:156-165. https://doi.org/10.1128/JB.129 .1.156-165.1977.

21. Bohin JP, Rigomier D, Schaeffer P. 1976. Ethanol sensitivity of sporulation in Bacillus subtilis: a new tool for the analysis of the sporulation process. J Bacteriol 127:934-940. https://doi.org/10.1128/JB.127.2.934-940.1976.

22. Walukiewicz HE, Tohidifar P, Ordal GW, Rao CV. 2014. Interactions among the three adaptation systems of Bacillus subtilis chemotaxis as revealed by an in vitro receptor-kinase assay. Mol Microbiol 93: 1104-1118. https://doi.org/10.1111/mmi.12721.

23. Cannistraro VJ, Glekas GD, Rao CV, Ordal GW. 2011. Cellular stoichiometry of the chemotaxis proteins in Bacillus subtilis. J Bacteriol 193 3220-3227. https://doi.org/10.1128/JB.01255-10.

24. Hou S, Larsen RW, Boudko D, Riley CW, Karatan E, Zimmer M, Ordal GW Alam M. 2000. Myoglobin-like aerotaxis transducers in Archaea and Bacteria. Nature 403:540-544. https://doi.org/10.1038/35000570.

25. Tohidifar P, Plutz MJ, Ordal GW, Rao CV. 2020. The mechanism of bidirectional $\mathrm{pH}$ taxis in Bacillus subtilis. J Bacteriol 202:e00491-19. https://doi.org/10.1128/JB.00491-19.

26. Reid MF, Fewson CA. 1994. Molecular characterization of microbial alcohol dehydrogenases. Crit Rev Microbiol 20:13-56. https://doi.org/10 3109/10408419409113545.

27. Zhang X, Hughes JG, Subuyuj GA, Ditty JL, Parales RE. 2019. Chemotaxis of Pseudomonas putida F1 to alcohols is mediated by the carboxylic acid 
receptor McfP. Appl Environ Microbiol 85:e01625-19. https://doi.org/10 .1128/AEM.01625-19.

28. Alexandre G. 2010. Coupling metabolism and chemotaxis-dependent behaviours by energy taxis receptors. Microbiology 156:2283-2293. https://doi.org/10.1099/mic.0.039214-0.

29. Nakano MM, Dailly YP, Zuber P, Clark DP. 1997. Characterization of anaerobic fermentative growth of Bacillus subtilis: identification of fermentation end products and genes required for growth. J Bacteriol 179:6749-6755. https://doi.org/10.1128/jb.179.21.6749-6755.1997.

30. Nakano MM, Hulett FM. 1997. Adaptation of Bacillus subtilis to oxygen limitation. FEMS Microbiol Lett 157:1-7. https://doi.org/10.1111/j.1574 -6968.1997.tb12744.x.

31. Leonardo MR, Cunningham PR, Clark DP. 1993. Anaerobic regulation of the adhE gene, encoding the fermentative alcohol dehydrogenase of Escherichia coli. J Bacteriol 175:870-878. https://doi.org/10.1128/jb.175 3.870-878.1993.

32. Walukiewicz HE, Ordal GW, Rao CV. 2018. In vitro assay for measuring receptor-kinase activity in the Bacillus subtilis chemotaxis pathway. Methods Mol Biol 1729:95-105. https://doi.org/10.1007/978-1-4939 -7577-8_10.

33. Bi S, Pollard AM, Yang Y, Jin F, Sourjik V. 2016. Engineering hybrid chemotaxis receptors in bacteria. ACS Synth Biol 5:989-1001. https:// doi.org/10.1021/acssynbio.6b00053.

34. Weerasuriya S, Schneider BM, Manson MD. 1998. Chimeric chemoreceptors in Escherichia coli: signaling properties of Tar-Tap and Tap-Tar hybrids. J Bacteriol 180:914-920. https://doi.org/10.1128/JB.180.4.914 $-920.1998$.

35. Rahman H, King RM, Shewell LK, Semchenko EA, Hartley-Tassell LE, Wilson JC, Day CJ, Korolik V. 2014. Characterisation of a multi-ligand binding chemoreceptor CcmL (Tlp3) of Campylobacter jejuni. PLoS Pathog 10:e1003822. https://doi.org/10.1371/journal.ppat.1003822.

36. Mayer M, Meyer B. 1999. Characterization of ligand binding by saturation transfer difference NMR spectroscopy. Angew Chem Int Ed Engl 38: 1784-1788. https://doi.org/10.1002/(SICI)1521-3773(19990614)38:12 $<$ 1784::AID-ANIE1784>3.0.CO;2-Q

37. Mayer M, Meyer B. 2001. Group epitope mapping by saturation transfer difference NMR to identify segments of a ligand in direct contact with a protein receptor. J Am Chem Soc 123:6108-6117. https://doi.org/10 $.1021 / \mathrm{ja0} 0100120$.

38. Cala O, Krimm I. 2015. Ligand-orientation based fragment selection in STD NMR screening. J Med Chem 58:8739-8742. https://doi.org/10 .1021/acs.jmedchem.5b01114.

39. Viegas A, Manso J, Nobrega FL, Cabrita EJ. 2011. Saturation-transfer difference (STD) NMR: a simple and fast method for ligand screening and characterization of protein binding. J Chem Educ 88:990-994. https:// doi.org/10.1021/ed101169t

40. Zhang W, Phillips GN, Jr. 2003. Structure of the oxygen sensor in Bacillus subtilis: signal transduction of chemotaxis by control of symmetry. Structure 11:1097-1110. https://doi.org/10.1016/S0969-2126(03)00169-2.

41. Zhang W, Olson JS, Phillips GN, Jr. 2005. Biophysical and kinetic characterization of HemAT, an aerotaxis receptor from Bacillus subtilis. Biophys J 88:2801-2814. https://doi.org/10.1529/biophysj.104.047936.

42. Hou S, Freitas T, Larsen RW, Piatibratov M, Sivozhelezov V, Yamamoto A Meleshkevitch EA, Zimmer M, Ordal GW, Alam M. 2001. Globin-coupled sensors: a class of heme-containing sensors in Archaea and Bacteria. Proc Natl Acad Sci U S A 98:9353-9358. https://doi.org/10.1073/pnas 161185598

43. Aono S, Kato T, Matsuki M, Nakajima H, Ohta T, Uchida T, Kitagawa $T$. 2002. Resonance Raman and ligand binding studies of the oxygensensing signal transducer protein HemAT from Bacillus subtilis. J Biol Chem 277:13528-13538. https://doi.org/10.1074/jbc.M112256200.

44. Mohd Azhar SH, Abdulla R, Jambo SA, Marbawi H, Gansau JA, Mohd Faik AA, Rodrigues KF. 2017. Yeasts in sustainable bioethanol production: a review. Biochem Biophys Rep 10:52-61. https://doi.org/10.1016/j.bbrep .2017.03.003.

45. Russo F, Cabrita M, Feio SS, Moiteiro C, Tavares R, Marcelo-Curto MJ, Roseiro JC. 2002. Antifungal activity of Bacillus species and Pseudomonas aeruginosa against filamentous fungi and yeasts, p 249-253. In Rauter AP, Palma FB, Justino J, Araújo ME, dos Santos SP (ed), Natural products in the new millennium: prospects and industrial application. Proceedings of the Phytochemical Society of Europe, vol 47. Springer, Dordrecht, Netherlands. https://doi.org/10.1007/978-94-015-9876-7_26.

46. Leifert C, Li H, Chidburee S, Hampson S, Workman S, Sigee D, Epton HA, Harbour A. 1995. Antibiotic production and biocontrol activity by Bacil- lus subtilis CL27 and Bacillus pumilus CL45. J Appl Bacteriol 78:97-108. https://doi.org/10.1111/j.1365-2672.1995.tb02829.x.

47. Podile AR, Prakash AP. 1996. Lysis and biological control of Aspergillus niger by Bacillus subtilis AF 1. Can J Microbiol 42:533-538. https://doi .org/10.1139/m96-072.

48. Ohimain El. 2016. Methanol contamination in traditionally fermented alcoholic beverages: the microbial dimension. Springerplus 5:1607. https://doi.org/10.1186/s40064-016-3303-1.

49. Yasueda H, Kawahara Y, Sugimoto S. 1999. Bacillus subtilis yckG and yckF encode two key enzymes of the ribulose monophosphate pathway used by methylotrophs, and yckH is required for their expression. J Bacteriol 181:7154-7160. https://doi.org/10.1128/JB.181.23.7154-7160.1999.

50. Yang YM, Pollard A, Hofler C, Poschet G, Wirtz M, Hell R, Sourjik V. 2015. Relation between chemotaxis and consumption of amino acids in bacteria. Mol Microbiol 96:1272-1282. https://doi.org/10.1111/mmi.13006.

51. Allard-Massicotte R, Tessier L, Lecuyer F, Lakshmanan V, Lucier JF, Garneau D, Caudwell L, Vlamakis H, Bais HP, Beauregard PB. 2016. Bacillus subtilis early colonization of Arabidopsis thaliana roots involves multiple chemotaxis receptors. mBio 7:e01664-16. https://doi.org/10.1128/mBio 01664-16

52. Tso WW, Adler J. 1974. Negative chemotaxis in Escherichia coli. J Bacteriol 118:560-576. https://doi.org/10.1128/JB.118.2.560-576.1974

53. Oku S, Hida A, Mattana T, Tajima T, Nakashimada Y, Kato J. 2017. Involvement of many chemotaxis sensors in negative chemotaxis to ethanol in Ralstonia pseudosolanacearum Ps29. Microbiology 163: 1880-1889. https://doi.org/10.1099/mic.0.000574.

54. Harris RA, Trudell JR, Mihic SJ. 2008. Ethanol's molecular targets. Sci Signal 1:re7. https://doi.org/10.1126/scisignal.128re7.

55. Dudley R. 2004. Ethanol, fruit ripening, and the historical origins of human alcoholism in primate frugivory. Integr Comp Biol 44:315-323. https://doi.org/10.1093/icb/44.4.315.

56. Alpi A, Beevers H. 1983. Effects of $\mathrm{O} 2$ concentration on rice seedlings. Plant Physiol 71:30-34. https://doi.org/10.1104/pp.71.1.30.

57. Setter T. 1994. Relationship between coleoptile elongation and alcoholic fermentation in rice exposed to anoxia. II. Cultivar differences. Ann Bot 74:273-279. https://doi.org/10.1006/anbo.1994.1118.

58. Kato-Noguchi H, Kugimiya T. 2001. Effects of ethanol on growth of rice seedlings. Plant Growth Regul 35:93-96. https://doi.org/10.1023/ A:1013850707053.

59. Mihic SJ, Ye Q, Wick MJ, Koltchine VV, Krasowski MD, Finn SE, Mascia MP, Valenzuela CF, Hanson KK, Greenblatt EP, Harris RA, Harrison NL. 1997. Sites of alcohol and volatile anaesthetic action on $G A B A(A)$ and glycine receptors. Nature 389:385-389. https://doi.org/10.1038/38738.

60. Taly A, Delarue M, Grutter T, Nilges M, Le Novere N, Corringer PJ, Changeux JP. 2005. Normal mode analysis suggests a quaternary twist model for the nicotinic receptor gating mechanism. Biophys J 88: 3954-3965. https://doi.org/10.1529/biophysj.104.050229.

61. Cheng MH, Cascio M, Coalson RD. 2007. Homology modeling and molecular dynamics simulations of the alpha1 glycine receptor reveals different states of the channel. Proteins 68:581-593. https://doi.org/10 .1002/prot.21435.

62. Ren H, Zhao Y, Wu M, Dwyer DS, Peoples RW. 2017. Two adjacent phenylalanines in the NMDA receptor GluN2A subunit M3 domain interactively regulate alcohol sensitivity and ion channel gating. Neuropharmacology 114:20-33. https://doi.org/10.1016/j.neuropharm.2016.11.013.

63. Shahidullah M, Harris T, Germann MW, Covarrubias M. 2003. Molecular features of an alcohol binding site in a neuronal potassium channel. Biochemistry 42:11243-11252. https://doi.org/10.1021/bi034738f.

64. Kruse SW, Zhao R, Smith DP, Jones DN. 2003. Structure of a specific alcohol-binding site defined by the odorant binding protein LUSH from Drosophila melanogaster. Nat Struct Biol 10:694-700. https://doi.org/10 $.1038 / \mathrm{nsb} 960$.

65. Howard RJ, Murail S, Ondricek KE, Corringer PJ, Lindahl E, Trudell JR, Harris RA. 2011. Structural basis for alcohol modulation of a pentameric ligand-gated ion channel. Proc Natl Acad Sci U S A 108:12149-12154. https://doi.org/10.1073/pnas.1104480108.

66. Dwyer DS, Bradley RJ. 2000. Chemical properties of alcohols and their protein binding sites. Cell Mol Life Sci 57:265-275. https://doi.org/10 .1007/PL00000689.

67. Khrustalev VV, Khrustaleva TA, Lelevich SV. 2017. Ethanol binding sites on proteins. J Mol Graph Model 78:187-194. https://doi.org/10.1016/j .jmgm.2017.10.017.

68. Altenbuchner J. 2016. Editing of the Bacillus subtilis genome by the 
CRISPR-Cas9 system. Appl Environ Microbiol 82:5421-5427. https://doi .org/10.1128/AEM.01453-16.

69. Labun K, Montague TG, Krause M, Torres Cleuren YN, Tjeldnes H, Valen E. 2019. CHOPCHOP v3: expanding the CRISPR Web toolbox beyond genome editing. Nucleic Acids Res 47:W171-W174. https://doi.org/10 .1093/nar/gkz365.

70. Engler C, Kandzia R, Marillonnet S. 2008. A one pot, one step, precision cloning method with high throughput capability. PLoS One 3:e3647. https://doi.org/10.1371/journal.pone.0003647.

71. Gibson DG, Young L, Chuang RY, Venter JC, Hutchison CA, III, Smith HO. 2009. Enzymatic assembly of DNA molecules up to several hundred kilobases. Nat Methods 6:343-345. https://doi.org/10.1038/nmeth.1318.

72. Anagnostopoulos C, Spizizen J. 1961. Requirements for transformation in Bacillus subtilis. J Bacteriol 81:741-746. https://doi.org/10.1128/JB.81 5.741-746.1961.

73. Ordal GW, Gibson KJ. 1977. Chemotaxis toward amino acids by Bacillus subtilis. J Bacteriol 129:151-155. https://doi.org/10.1128/JB.129.1.151 $-155.1977$.

74. Kagi JH, Vallee BL. 1960. The role of zinc in alcohol dehydrogenase. V. The effect of metal-binding agents on the structure of the yeast alcohol dehydrogenase molecule. J Biol Chem 235:3188-3192.

75. Balouiri M, Sadiki M, Ibnsouda SK. 2016. Methods for in vitro evaluating antimicrobial activity: a review. J Pharm Anal 6:71-79. https://doi.org/10 .1016/j.jpha.2015.11.005.

76. Schneider CA, Rasband WS, Eliceiri KW. 2012. NIH Image to ImageJ: 25 years of image analysis. Nat Methods 9:671-675. https://doi.org/10 .1038/nmeth.2089.

77. Savitzky A, Golay MJE. 1964. Smoothing and differentiation of data by simplified least squares procedures. Anal Chem 36:1627-1639. https:// doi.org/10.1021/ac60214a047.

78. Micsonai A, Wien F, Bulyaki E, Kun J, Moussong E, Lee YH, Goto Y, Refregiers M, Kardos J. 2018. BeStSel: a Web server for accurate protein secondary structure prediction and fold recognition from the circular dichroism spectra. Nucleic Acids Res 46:W315-W322. https://doi.org/10 .1093/nar/gky497.

79. Potter SC, Luciani A, Eddy SR, Park Y, Lopez R, Finn RD. 2018. HMMER Web server: 2018 update. Nucleic Acids Res 46:W200-W204. https://doi .org/10.1093/nar/gky448.

80. Edgar RC. 2004. MUSCLE: a multiple sequence alignment method with reduced time and space complexity. BMC Bioinformatics 5:113. https:// doi.org/10.1186/1471-2105-5-113.

81. Rice P, Longden I, Bleasby A. 2000. EMBOSS: the European Molecular Biology Open Software Suite. Trends Genet 16:276-277. https://doi.org/ 10.1016/s0168-9525(00)02024-2.

82. Webb B, Sali A. 2016. Comparative protein structure modeling using MODELLER. Curr Protoc Bioinformatics 54:5.6.1-5.6.37. https://doi.org/ 10.1002/cpbi.3.

83. Park SY, Borbat PP, Gonzalez-Bonet G, Bhatnagar J, Pollard AM, Freed JH, Bilwes AM, Crane BR. 2006. Reconstruction of the chemotaxis receptorkinase assembly. Nat Struct Mol Biol 13:400-407. https://doi.org/10 $.1038 /$ nsmb1085.
84. Krivov GG, Shapovalov MV, Dunbrack RL, Jr. 2009. Improved prediction of protein side-chain conformations with SCWRL4. Proteins 77:778-795. https://doi.org/10.1002/prot.22488.

85. Krieger E, Joo K, Lee J, Lee J, Raman S, Thompson J, Tyka M, Baker D, Karplus K. 2009. Improving physical realism, stereochemistry, and sidechain accuracy in homology modeling: four approaches that performed well in CASP8. Proteins 77(Suppl 9):114-122. https://doi.org/10.1002/ prot. 22570 .

86. Laskowski RA, MacArthur MW, Moss DS, Thornton JM. 1993. PROCHECK: a program to check the stereochemical quality of protein structures. J Appl Crystallogr 26:283-291. https://doi.org/10.1107/S0021889892009944.

87. Humphrey W, Dalke A, Schulten K. 1996. VMD: visual molecular dynamics. J Mol Graph 14:33-38. https://doi.org/10.1016/0263-7855(96)00018-5.

88. Morris GM, Huey R, Lindstrom W, Sanner MF, Belew RK, Goodsell DS, Olson AJ. 2009. AutoDock4 and AutoDockTools4: automated docking with selective receptor flexibility. J Comput Chem 30:2785-2791. https:// doi.org/10.1002/jcc.21256.

89. Phillips JC, Braun R, Wang W, Gumbart J, Tajkhorshid E, Villa E, Chipot C, Skeel RD, Kale L, Schulten K. 2005. Scalable molecular dynamics with NAMD. J Comput Chem 26:1781-1802. https://doi.org/10.1002/jcc.20289.

90. Huang J, MacKerell AD, Jr. 2013. CHARMM36 all-atom additive protein force field: validation based on comparison to NMR data. J Comput Chem 34:2135-2145. https://doi.org/10.1002/jcc.23354.

91. Cassidy CK, Himes BA, Sun D, Ma J, Zhao G, Parkinson JS, Stansfeld PJ, Luthey-Schulten Z, Zhang P. 2020. Structure and dynamics of the E. coli chemotaxis core signaling complex by cryo-electron tomography and molecular simulations. Commun Biol 3:24. https://doi.org/10.1038/ s42003-019-0748-0.

92. Walshaw J, Woolfson DN. 2001. Socket: a program for identifying and analysing coiled-coil motifs within protein structures. J Mol Biol 307: 1427-1450. https://doi.org/10.1006/jmbi.2001.4545.

93. Swain KE, Gonzalez MA, Falke JJ. 2009. Engineered socket study of signaling through a four-helix bundle: evidence for a yin-yang mechanism in the kinase control module of the aspartate receptor. Biochemistry 48:9266-9277. https://doi.org/10.1021/bi901020d.

94. Hills EE, Abraham MH, Hersey A, Bevan CD. 2011. Diffusion coefficients in ethanol and in water at 298K: linear free energy relationships. Fluid Phase Equilib 303:45-55. https://doi.org/10.1016/j.fluid.2011.01.002.

95. Logg A, Mardal K-A, Wells G (ed). 2012. Automated solution of differential equations by the finite element method. Springer-Verlag, Berlin, Germany.

96. Geuzaine C, Remacle J-F. 2009. Gmsh: a 3-D finite element mesh generator with built-in pre- and post-processing facilities. Int J Numer Methods Eng 79:1309-1331. https://doi.org/10.1002/nme.2579.

97. Ullah $A H$, Ordal GW. 1981. In vivo and in vitro chemotactic methylation in Bacillus subtilis. J Bacteriol 145:958-965. https://doi.org/10.1128/JB .145.2.958-965.1981.

98. Kristich CJ, Ordal GW. 2002. Bacillus subtilis CheD is a chemoreceptor modification enzyme required for chemotaxis. J Biol Chem 277: 25356-25362. https://doi.org/10.1074/jbc.M201334200. 